\title{
Ogólnopolski Program Leczenia Ciężkiego Niedoboru Hormonu Wzrostu u Osób Dorosłych oraz u Młodzieży po Zakończeniu Terapii Promującej Wzrastanie
}

\author{
Andrzej Lewiński ${ }^{1,2}$, Joanna Smyczyńska², Renata Stawerska², Maciej Hilczer ${ }^{2,3}$, Magdalena Stasiak2 \\ Tomasz Bednarczuk, Marek Bolanowski ${ }^{5}$, Roman Junik ${ }^{6}$, Marek Ruchała ${ }^{7}$, Anhelli Syrenicz ${ }^{8}$, \\ Mieczysław Walczak', Wojciech Zgliczyński ${ }^{10}$, Małgorzata Karbownik-Lewińska ${ }^{2,11}$ \\ ${ }^{1}$ Klinika Endokrynologii i Chorób Metabolicznych, Uniwersytet Medyczny, Łódź \\ ${ }^{2}$ Klinika Endokrynologii i Chorób Metabolicznych, Instytut Centrum Zdrowia Matki Polki, Łódź \\ ${ }^{3}$ Klinika Endokrynologii Wieku Rozwojowego, Uniwersytet Medyczny, Łódź \\ ${ }^{4}$ Klinika Chorób Wewnętrznych i Endokrynologii, Warszawski Uniwersytet Medyczny, Warszawa \\ ${ }^{5}$ Klinika Endokrynologii, Diabetologii i Leczenia Izotopami, Uniwersytet Medyczny im. Piastów Ślaskich, Wrocław \\ ${ }^{6}$ Klinika Endokrynologii i Diabetologii, Collegium Medicum w Bydgoszczy, Uniwersytet Mikotaja Kopernika, Torun \\ ${ }^{7}$ Klinika Endokrynologii, Przemiany Materii i Chorób Wewnętrznych, Uniwersytet Medyczny, Poznań \\ ${ }^{8}$ Klinika Endokrynologii, Chorób Metabolicznych i Chorób Wewnętrznych, Pomorski Uniwersytet Medyczny, Szczecin \\ ${ }^{9}$ Klinika Pediatrii, Endokrynologii, Diabetologii, Chorób Metabolicznych i Kardiologii Wieku Rozwojowego, Pomorski Uniwersytet \\ Medyczny, Szczecin \\ ${ }^{10}$ Klinika Endokrynologii Centrum Medycznego Kształcenia Podyplomowego, Warszawa \\ ${ }^{11}$ Zakład Endokrynologii Onkologicznej, Uniwersytet Medyczny, Łódź
}

Artykut jest tłumaczeniem pracy: Lewiński A, Smyczyńska J., Stawerska R., Hilczer M., Stasiak M., Bednarczuk T., Bolanowski M., Junik R., Ruchała M., Syrenicz A., Walczak M., Zgliczyński W., Karbownik-Lewińska M. National Program of Severe Growth Hormone Deficiency Treatment in Adults and Adolescents after Completion of Growth Promoting Therapy. Endokrynol Pol 2018; 69 (5): $468-496$

Należy cytować wersję pierwotna.

Piśmiennictwo dostępne w wersji pierwotnej na stronach 481-483

\begin{abstract}
Streszczenie
Od 60 lat hormon wzrostu (GH, growth hormone) znajduje zastosowanie w terapii niskorosłych dzieci z niedoborem GH (GHD, GH deficiency), zaś od około 30 lat — również w terapii osób dorosłych z GHD, u których leczenie to prowadzone jest ze wskazań metabolicznych. W Polsce leczenie GH podlega refundacji jedynie u dzieci z GHD, natomiast jak dotąd nie było refundowane u osób dorosłych z GHD. Osoby dorosłe lub młodzież po zakończeniu procesu wzrastania, z GHD, które wymagają terapii GH, kwalifikuje się do dwóch grup: GHD, który wystąpił w wieku dziecięcym (childhood-onset GHD - CO-GHD) oraz GHD nabyty w wieku dorosłym (AO-GHD, adult-onset GHD). W pracy przedstawiono krótki zarys historii leczenia GH u ludzi. Omówiono najnowsze dane na temat przyczyn i objawów GHD u osób dorosłych oraz powikłania nieleczonego GHD. Opisano aktualne zalecenia dotyczące diagnostyki oraz leczenia i monitorowania terapii GH u osób dorosłych. W podsumowaniu zaprezentowano cele, założenia oraz schemat realizacji „Ogólnopolskiego Programu Leczenia Niedoboru Hormonu Wzrostu u Osób Dorosłych oraz Młodzieży po zakończeniu Terapii Promującej Wzrastanie”, jak również spodziewane efekty zdrowotne i ekonomiczne wprowadzenia leczenia GH u osób dorosłych z GHD w Polsce. (Endokrynol Pol 2018; 69 (5): 497-524)

Słowa kluczowe: program lekowy; leczenie hormonem wzrostu; niedobór hormonu wzrostu, który wystąpił w wieku dziecięcym (childhoodonset GHD); niedobór hormonu wzrostu nabyty w wieku dorosłym (adult-onset GHD)
\end{abstract}

\section{Wprowadzenie}

Od 60 lat hormon wzrostu (GH, growth hormone) znajduje zastosowanie w leczeniu dzieci z zaburzeniami wzrastania, przede wszystkim związanymi z niedoborem GH (GHD, GH deficiency), czyli somatotropinową niedoczynnością przysadki (SNP). Od około 30 lat do terapii kwalifikowane są również osoby dorosłe z GHD, u których leczenie to prowadzone jest ze wskazań metabolicznych. W Polsce obecnie uznane zastosowania rekombinowanego ludzkiego GH (rhGH) podlegające refundacji terapii to SNP u dzieci, niedobór wzrostu 
w przebiegu przewlekłej niewydolności nerek, w zespole Turnera, w zespole Pradera-Williego oraz u dzieci niskorosłych urodzonych z hipotrofią wewnątrzmaciczną lub zbyt małych w porównaniu do czasu trwania ciąży, natomiast dotychczas nie jest refundowane leczenie GHD u osób dorosłych.

Ostatnie dekady XX wieku przyniosły gwałtowny rozwój wiedzy o roli GH nie tylko w procesach wzrastania, lecz także w regulacji procesów metabolicznych. Poza podstawowym działaniem stymulującym wzrost kości, chrząstki i tkanki łącznej, GH wpływa także na gospodarkę lipidową, węglowodanową, białkową i wodno-elektrolitową [1].

Jednocześnie, zdefiniowano ciężki GHD u osób dorosłych jako odrębną jednostkę chorobową, wymagająca precyzyjnego zdiagnozowania i prawidłowego leczenia substytucyjnego [2]. Najpoważniejsze konsekwencje długotrwałego, ciężkiego GHD w populacji osób dorosłych związane są ze zwiększoną częstością zgonów z powodu powikłań sercowo-naczyniowych oraz złamań kości na tle osteoporozy, a także z pogorszeniem jakości życia. Z tego względu ciężki GHD stwierdzany u osoby dorosłej jest wskazaniem do zastosowania leczenia substytucyjnego preparatem rhGH. W ostatnich latach zwrócono szczególną uwagę na możliwość wystąpienia zaburzeń metabolicznych związanych z GHD u pacjentów leczonych w dzieciństwie preparatami rhGH, którzy zakończyli terapię promującą wzrastanie [3].

Pierwsze rekomendacje dotyczące rozpoznawania i leczenia GHD u osób dorosłych zostały opracowane w 1997 r. przez GH Research Society [2]. Po upływie kolejnych 20 lat rekomendacje te zostały zaktualizowane i ustalono wspólne stanowisko Towarzystw Endokrynologicznych z Europy, ze Stanów Zjednoczonych, z Japonii i Australii [4]. W ostatnich 10 latach ukazał się szereg publikacji dotyczących zarówno powikłań nieleczonego GHD u osób dorosłych, jak i optymalizacji postępowania terapeutycznego w tej grupie chorych. W 1999 r. zagadnienia dotyczące terapii rhGH osób dorosłych były przedmiotem publikacji w Suplemencie Endokrynologii Polskiej, a w 2000 r. zespół lekarzy pod kierunkiem prof. dr. hab. Andrzeja Lewińskiego opracował „Ogólnopolski Program Leczenia Hormonem Wzrostu Ludzi Dorosłych” [5] , który jednak nie doczekał się realizacji.

Obecnie w Polsce refundacji podlega leczenie preparatami rhGH w celu promocji wzrastania, prowadzone w ramach Programów Lekowych u dzieci z somatotropinową niedoczynnością przysadki, zespołem Turnera, zespołem Pradera-Williego, niedoborem wzrostu w przebiegu przewlekłej niewydolności nerek, a także $\mathrm{u}$ dzieci urodzonych jako zbyt małe $\mathrm{w}$ porównaniu do czasu trwania ciąży (z SGA lub IUGR). Stosowanie preparatów rhGH u osób dorosłych po zakończeniu wzrastania nie jest obecnie refundowane, $\mathrm{z}$ wyjątkiem pacjentów z zespołem Pradera-Williego leczonych $\mathrm{w}$ dzieciństwie, u których terapia po zakończeniu wzrastania prowadzona jest ze wskazań metabolicznych. Według aktualnego stanu wiedzy, również w przypadku ciężkiego GHD kontynuacja terapii preparatami rhGH ma istotne znaczenie dla zapobiegania powikłaniom związanym z występującymi w tej grupie chorych zaburzeniami metabolicznymi i pogorszeniem jakości życia. Nie ma natomiast obecnie przekonujących danych wskazujących na celowość kontynuacji leczenia preparatami rhGH osób dorosłych otrzymujących w dzieciństwie preparaty rhGH w innych wskazaniach niż ciężki GHD i zespół Pradera-Williego.

\section{Niedobór hormonu wzrostu u osób dorosłych}

\subsection{Definicja}

Niedobór GH jest to upośledzenie wydzielania GH przez komórki somatotropowe przysadki.

U osób dorosłych jako jednostkę chorobową zdefiniowano jedynie ciężki GHD, natomiast - w przeciwieństwie do klasyfikacji stosowanej u dzieci - nie rozpoznaje się tak zwanego częściowego GHD [4, 6]. W klasyfikacji tej jednostki chorobowej u osób dorosłych wyróżnia się obecnie:

- GHD, który wystąpił w wieku dziecięcym (CO-GHD, childhood-onset GHD),

- GHD nabyty w wieku dorosłym (AO-GHD, adult-onset GHD).

\subsection{Przyczyny niedoboru hormonu wzrostu} u osób dorostych - zagadnienia epidemiologiczne Brakuje dokładnych badań epidemiologicznych dotyczaccych występowania GHD u ludzi dorosłych w Polsce. Badania populacyjne przeprowadzone w Hiszpanii w latach 90. XX wieku określiły częstość występowania różnych postaci niedoczynności przysadki u dorosłych (chorobowość) na 45,5:100 000, a liczbę nowych przypadków na rok (zachorowalność) na 4,2:100 000 [7], co w ostatnich latach zweryfikowano, oceniając w tej samej populacji chorobowość na 37,5:100 000 a zachorowalność na 2,07:100 000 [8]. Badania przeprowadzone w Danii w latach 1980-1999 określiły zachorowalność na AO-GHD na 1,9:100 000 u mężczyzn i 1,4:100 000 u kobiet [9], we Francji w latach 1994-1995 zachorowalność na AO-GHD oceniono na 1,2:100 000 [10]. Przyjmując podobną częstość AO-GHD w populacji polskiej oraz liczbę osób dorosłych 315000000 (dane Głównego Urzędu Statystycznego za 2016 r.), można oszacować zachorowalność na AO-GHD w Polsce na około 400 przypadków rocznie, przy czym trudno jest ocenić, 
jaki odsetek tych pacjentów będzie spełniać kryteria kwalifikacji do terapii rhGH.

Ze względu na odmienne kryteria rozpoznania GHD u dzieci i ciężkiego GHD u osób dorosłych, część pacjentów z CO-GHD leczonych w dzieciństwie preparatami rhGH nie ma wskazań do kontynuacji leczenia jako osoby dorosłe. $Z$ tego względu wymagana jest $u$ nich ponowna ocena wydzielania GH po zakończeniu terapii promującej wzrastanie. Dane epidemiologiczne dotyczące częstości występowania trwałego GHD według różnych opracowań są rozbieżne, w piśmiennictwie podawane są zarówno wartości wysokie sięgające ponad 70\% [11], jak i znacznie niższe, w granicach 30\% [12], a nawet poniżej 20\% [13]. Różnice te najprawdopodobniej wynikają zarówno z odmiennych kryteriów rozpoznania GHD w dzieciństwie i w wieku dorosłym, stosowanych przez różnych autorów, jak i z odmienności populacji objętych analizą. $\mathrm{W}$ materiale obejmującym pacjentów z izolowanym CO-GHD leczonych $w$ dzieciństwie preparatami rhGH w Klinice Endokrynologii i Chorób Metabolicznych ICZMP oceniono częstość trwałego ciężkiego GHD po zakończeniu terapii promującej wzrastanie na 12\% [14], podczas gdy w grupie chorych ze zmianami organicznymi w okolicy przysadki (np. z zespołem przerwania szypuły przysadki czy po zabiegach neurochirurgicznych z powodu czaszkogardlaka) trwały GHD dotyczył wszystkich pacjentów [15]. Biorąc pod uwagę liczbę dzieci leczonych obecnie z powodu somatotropinowej niedoczynności przysadki, można szacunkowo ocenić, że w skali kraju około 50 pacjentów rocznie będzie spełniało kryteria rozpoznania ciężkiego CO-GHD, a tym samym - kryteria kwalifikacji do terapii rhGH $\mathrm{w}$ wieku dorosłym.

Zgodnie z danymi KIMS (Pfizer International Metabolic Database, dawniej Pharmacia) opublikowanymi w 2009 r. do najczęstszych przyczyn GHD u osób dorosłych zalicza się guzy przysadki (44\%) oraz czaszkogardlaki $(11 \%)$, rzadsze przyczyny to radioterapia guzów mózgu (7\%), urazy mózgu i zespół Sheehana (po około 3\%) oraz limfocytarne zapalenie przysadki $(1 \%)$, natomiast u około $16 \%$ pacjentów ustalono rozpoznanie idiopatycznego GHD [16]. W badaniu HypoCCS (The Hypopituitary Control and Complications Study, Eli Lilly) guzy przysadki stanowiły $38,6 \%$, czaszkogardlaki-8,4\%, a krwawienia do przysadki $-2,8 \%$ przyczyn GHD u osób dorosłych, podczas gdy idiopatyczny GHD rozpoznano w 19,3\% przypadków [17]. W porównaniu z wcześniejszymi doniesieniami $[18,19]$, wzrasta odsetek pacjentów po urazach oraz po naświetlaniach głowy z innych przyczyn niż guzy przysadki i okolicy nadsiodłowej, a także z rozpoznaniem idiopatycznego GHD [17]. U pacjentów z gruczolakami przysadki w momencie ich rozpoznania stwierdza się GHD w około 50\% przypadków, natomiast częstość tego zaburzenia wzrasta nawet do $80 \%$ po zabiegu neurochirurgicznym i do $100 \%$ w ciągu 5 lat po następczej radioterapii [20]. Należy mieć na uwadze fakt, że niedoczynność przysadki, obejmująca również upośledzone wydzielanie GH, może także dotyczyć pacjentów uprzednio leczonych z powodu akromegalii [21].

\subsection{Objawy kliniczne i zaburzenia metaboliczne w przypadku niedoboru hormonu wzrostu u osób dorostych}

\subsubsection{Objawy podmiotowe}

- Osłabienie i łatwa męczliwość, uczucie stałego zmęczenia;

- Obniżenie nastroju;

- Zmniejszenie energii życiowej;

- Pogorszenie kontaktów społecznych z nasiloną tendencją do izolacji;

- Zaburzenie reakcji emocjonalnych;

- Poczucie pogorszenia jakości życia;

- Brak poczucia zdrowia.

\subsubsection{Objawy przedmiotowe}

- Obniżenie masy mięśniowej ze zmniejszeniem siły mięśni i wydolności fizycznej;

- Wzrost masy tłuszczowej ciała, tzw. "tkanka tłuszczowa centralna", zwiększenie grubości fałdu skóry i tkanki tłuszczowej w nadbrzuszu, wzrost wskaźnika talia: biodra (WHR, waist-hip ratio);

- Skóra blada, zwłaszcza na twarzy, sucha, cienka, mało elastyczna, widoczne liczne drobne zmarszczki pionowe i poziome na czole;

- Owłosienie głowy przerzedzone, włosy miękkie, jedwabiste, cienkie;

- Meszek na przedramionach, przerzedzone owłosienie dołów pachowych i okolicy łonowej;

- Pocenie u chorych wyraźnie zmniejszone, na skutek zmian zanikowych gruczołów potowych;

- Często nadciśnienie tętnicze i cechy niewydolności krążenia [22].

\subsubsection{Zmiany obserwowane $w$ badaniach \\ dodatkowych}

- Zaburzenia gospodarki lipidowej sprzyjające rozwojowi miażdżycy (wzrost stężenia cholesterolu całkowitego, LDL-cholesterolu i triglicerydów, obniżenie HDL-cholesterolu);

- Zmiany zanikowe mięśnia lewej komory serca;

- Obniżenie gęstości mineralnej kości (osteoporoza, T score $<-2,5 \mathrm{SD}$ );

- Zaburzenia funkcji nerek (obniżenie filtracji kłębkowej i przepływu nerkowego) [23, 24]. 


\subsubsection{Zaburzenia metaboliczne}

\subsubsection{Gospodarka lipidowa}

Hormon wzrostu ma działanie lipolityczne, powoduje hydrolizę triglicerydów tkanki tłuszczowej z uwolnieniem wolnych kwasów tłuszczowych (WKT) do krążenia. Ponadto, nasila procesy oksydacji lipidów oraz powstawanie ciał ketonowych [25]. Dorośli z GHD zwykle prezentują androidalny typ otyłości oraz zwiększoną o około 10\% zawartość tkanki tłuszczowej $\mathrm{w}$ organizmie. Ponadto stwierdza się aterogenny profil lipidowy w tej grupie chorych: podwyższone stężenie cholesterolu całkowitego, LDL-cholesterolu, triglicerydów, apolipoproteiny B, natomiast obniżone stężenie HDL-cholesterolu.

Od ponad 20 lat wiadomo, że leczenie substytucyjne $\mathrm{z}$ zastosowaniem rhGH poprawia parametry gospodarki lipidowej [26], redukuje procentową zawartość tłuszczu w organizmie, a tym samym obniża ryzyko chorób układu krążenia [27]. Długotrwałe, co najmniej kilkuletnie, stosowanie preparatów rhGH u osób dorosłych z GHD obniża stężenie cholesterolu całkowitego i LDL-cholesterolu i jednocześnie powoduje wzrost stężenia HDL-cholesterolu [28, 29]. U osób dorosłych z GHD zwiększona peroksydacja lipidów obniża się $\mathrm{w}$ warunkach substytucji rhGH $[25,30]$.

Przerwanie terapii rhGH po zakończeniu wzrastania powoduje u pacjentów z ciężkim GHD wzrost stężenia cholesterolu całkowitego i LDL-cholesterolu oraz zwiększenie tłuszczowej masy ciała i wzrost ciśnienia tętniczego (zwłaszcza skurczowego) [31]. Zaburzenia te są odwracalne po ponownym włączeniu terapii rhGH [31, 32].

\subsubsection{Gospodarka weglowodanowa}

Wpływ GH na metabolizm węglowodanów jest złożony. Hormon wzrostu, działając bezpośrednio na metabolizm węglowodanów, działa antagonistycznie w stosunku do insuliny; działając pośrednio — poprzez insulinopodobny czynnik wzrostu-I (IGF-I, insulin-like growth factor-I) - ma działanie insulinopodobne [33]. Hormon wzrostu hamuje transport glukozy do tkanek i utlenianie glukozy, nasila zaś glukoneogenezę w wątrobie, co w efekcie doprowadza do wzrostu stężenia glukozy we krwi. Sugeruje się, że GH jest silnym hormonem przeciwdziałającym hipoglikemii. Jest on odpowiedzialny również za "zjawisko brzasku” (dawn phenomenon), polegające na obniżonej wrażliwości na insulinę $w$ godzinach rannych.

U chorych z GHD występuje insulinooporność prawdopodobnie związana z nagromadzeniem trzewnej tkanki tłuszczowej [34], obserwuje się podwyższenie stężenia insuliny na czczo, zwiększoną częstość cukrzycy typu 2 lub podwyższonego stężenia hemoglobiny glikowanej u osób bez cukrzycy, skorelowane z wyższymi wartościami wskaźnika masy ciała (BMI, body mass index) [35].

Leczenie substytucyjne $\mathrm{z}$ zastosowaniem rhGH w wieku dojrzałym nasila insulinooporność, lecz pomimo obserwowanej hiperinsulinemii nie stwierdza się pogorszenia metabolizmu węglowodanów. Doniesienia z ostatnich lat wskazują, że początkowe, niekorzystne efekty rhGH są całkowicie odwracalne podczas długotrwałej terapii. Opisywany jest dwufazowy wpływ substytucji rhGH na gospodarkę węglowodanową $\mathrm{w}$ początkowym okresie podstawowe znaczenie ma niekorzystne działanie hamujące tkankowe zużycie glukozy, a w okresie wieloletnim zaczynają przeważać korzystne efekty związane ze zmianami dotyczącymi składu ciała (przede wszystkim ze zmniejszeniem ilości tkanki tłuszczowej trzewnej) [28, 36]. W przypadku ciężkiego GHD szczególnie korzystne jest stosowanie niskich dawek rhGH, które zwiększają insulinowrażliwość, co może mieć korzystny wpływ na obniżenie ryzyka cukrzycy typu $2 \mathrm{w}$ tej grupie chorych [37].

\subsubsection{Metabolizm białek}

Hormon wzrostu ma działanie anaboliczne na metabolizm białek. Stwierdzono, że GH pobudza syntezę białka w mięśniach szkieletowych oraz w mięśniu sercowym, ułatwia transport aminokwasów oraz ich wbudowanie w cząsteczki białka. Powoduje także dodatni bilans azotowy poprzez obniżenie stężenia krążących aminokwasów i mocznika. U chorych z niedoborem GH wykazano obniżony transport aminokwasów do komórki oraz obniżoną biosyntezę białka [38].

Leczenie substytucyjne z zastosowaniem GH zwiększa biosyntezę białka [38].

\subsubsection{Gospodarka wodno-elektrolitowa}

Hormon wzrostu powoduje zatrzymanie jonów sodu $\mathrm{w}$ organizmie. Sugeruje się, iż działanie antynatriuretyczne GH jest spowodowane wpływem na zwiększenie aktywności pompy sodowej w kanalikach nerkowych. Hormon wzrostu ma również działanie stymulujące na układ renina-angiotensyna-aldosteron (RAA, renin-angiotensin-aldosterone). Powoduje wzrost zawartości wody w ustroju, a zwłaszcza wzrost objętości wody w przestrzeni pozakomórkowej $[23,27,39-41]$.

\subsubsection{Konsekwencje długotrwałego GHD u osób dorosłych. Efekty leczenia substytucyjnego}

Jako najpoważniejsze konsekwencje długotrwałego GHD u osób dorosłych należy wymienić:

- zwiększoną częstość zgonów z powodu powikłań sercowo-naczyniowych;

- częste złamania kości na tle osteoporozy;

— pogorszenie jakości życia [36]. 


\subsubsection{Wptyw na układ sercowo-naczyniowy}

Ciężki GHD u osób dorosłych jest istotnym czynnikiem ryzyka chorób układu sercowo-naczyniowego i zwiększonej umieralności z tego powodu [36]. Niekorzystny wpływ GHD na układ sercowo-naczyniowy zachodzi przede wszystkim poprzez zaburzenia gospodarki węglowodanowej i lipidowej [28, 36]. W ostatnich latach zwrócono uwagę także na znaczenie stresu oksydacyjnego [25, 30], zwiększonego wydzielania cytokin prozapalnych i czynników prokoagulacyjnich oraz dysfunkcję śródbłonka naczyń krwionośnych w patomechanizmie zaburzeń związanych z GHD [36]. Zaburzenia te są przynajmniej częściowo odwracalne w warunkach substytucji rhGH $[28,42]$.

U pacjentów z ciężkim GHD stwierdza się obniżenie masy mięśnia lewej komory serca, upośledzenie kurczliwości, obniżenie frakcji wyrzutowej i zaburzenia fazy rozkurczu oraz zmniejszenie rezerwy czynnościowej serca [36, 43]. Substytucyjne zastosowanie GH powoduje pogrubienie ściany i zwiększenie masy lewej komory, zwiększenie frakcji wyrzutowej i liczby włókienek mięśniowych, zwiększenie spoczynkowej końcoworozkurczowej objętości lewej komory, objętości wyrzutowej, a także zmniejszenie obwodowego oporu naczyniowego [23, 27, 44].

\subsubsection{Wptyw na uktad mięśniowy}

Hormon wzrostu działa w sposób pośredni na mięśnie poprzez IGF-I. Czynnik ten, wiążąc się ze specyficznym receptorem na powierzchni mioblastów, nasila w komórkach mięśni szereg procesów anabolicznych [45].

U dorosłych chorych z niedoborem GH zastosowanie tego hormonu zwiększa masę i siłę mięśni szkieletowych [46].

\subsubsection{Wptyw na uktad kostny}

Hormon wzrostu zwiększa obrót kostny, gęstość mineralną kości (BMD, bone mineral density) oraz zawartość minerałów w kościach (BMC, bone mineral content) $[47,48]$. Działa on na kości w sposób bezpośredni i pośredni. Bezpośrednio poprzez swoiste receptory zlokalizowane w osteoblastach stymuluje aktywność i proliferację osteoblastów. Ponadto zwiększa liczbę i różnicowanie osteoklastów [49]. Wpływ GH na kości polega zatem na przyspieszeniu obrotu kostnego (bone turnover), ze zwiększeniem wytwarzania, a jednocześnie resorpcji kostnej, z przewagą procesów tworzenia [50].

Pośrednie oddziaływanie GH na kości zachodzi z udziałem IGF-I i białko wiążące insulinopodobny czynnik wzrostu 3 (IGFBP-3) produkowanych w wątrobie oraz wytwarzanych miejscowo przez osteoblasty. Na lokalne wytwarzanie IGF-I w tkance kostnej mają również wpływ estrogeny, kortyzol, a także parathormon [51]. Syntetyzowany w osteoblastach IGF-I może działać w sposób autokrynny i parakrynny, odgrywając ważną rolę w regulacji gęstości tkanki kostnej [52]. IGFBP-3 potęguje wpływ IGF-I na proliferację osteoblastów i zwiększa wytwarzanie kolagenu typu I w osteoblastach [53].

Hormon wzrostu pośrednio wpływa również na tkankę kostną poprzez zwiększenie masy i siły mięśni szkieletowych oraz na wydolność mięśnia serca. Tym samym wzmaga aktywność fizyczną, co stymuluje aktywność osteoblastów i zwiększa masę kostną [46, 54]. Działając na gonady zwiększa sekrecję estrogenów i testosteronu, potęgując ich korzystny wpływ na tkankę kostną [55, 56]. Hormon wzrostu, działając na nerki, aktywuje 1-alfa-hydroksylazę i zwiększa syntezę $1,25(\mathrm{OH})_{2} \mathrm{D}_{3}$ oraz - poprzez IGF-I — zwiększa reabsorpcję fosforanów w cewkach nerkowych. Działając na nerki i jelita, wywołuje dodatni bilans wapnia [51].

Niedobór GH u osób dorosłych skojarzony jest z obniżeniem BMD i BMC oraz ze zwiększonym ryzykiem złamań [47]. Terapia rhGH skutkuje u tych chorych początkowo niewielkim obniżeniem BMD z jej następczym przyrostem po 2 latach leczenia postępującym aż do 5-7 roku terapii, po czym obserwowana jest stabilizacja wartości BMD i BMC. Najbardziej korzystne efekty daje stosowanie dawek rhGH pozwalających na utrzymanie stężenia IGF-I w zakresie normy wiekowej, podczas gdy wyższe dawki początkowe rhGH zmniejszają skuteczność terapii wieloletniej [47].

Wiadomo, że szczytowa masa kostna osiągana jest w ciągu 1-7 lat po zakończeniu wzrastania $[57,58]$. U młodzieży oraz u młodych dorosłych z CO-GHD obserwuje się po zaprzestaniu terapii rhGH obniżenie BMD oraz zmniejszenie grubości kości korowej, co $\mathrm{w}$ efekcie prowadzi do zwiększonego ryzyka złamań kości $[59,60]$. Również u tych pacjentów po ponownym włączeniu rhGH obserwowany jest początkowy niewielki spadek, a następnie istotny wzrost BMD w porównaniu z grupą nieleczoną [59].

\subsubsection{Wptyw na gonady}

Hormon wzrostu reguluje funkcję osi podwzgórze-przysadka-gonady. Na drodze parakrynnej pobudza komórki gonadotropowe przysadki do produkcji i wydzielania gonadotropin. Nasila wrażliwość komórek Leydiga i Sertoliego na działanie gonadotropin przez zwiększenie gęstości receptorów dla folitropiny (FSH) i lutropiny (LH), nasila również wrażliwość jajników na gonadotropiny, powodując zwiększenie produkcji estradiolu i progesteronu. Działa również bezpośrednio, wiążąc się ze swymi receptorami w komórkach ziarnistych oraz komórkach ciałka żółtego w jajnikach, przez co zwiększa wytwarzanie odpowiednio estradiolu i progesteronu, stymuluje również lokalną produkcję IGF-I w jądrach [55, 56]. 
U pacjentek z wielohormonalną niedoczynnością przysadki otrzymujących leczenie substytucyjne preparatami gonadotropin (FSH-hCG), L-tyroksyny i hydrokortyzonu, jak również u pacjentek z izolowanym GHD, substytucja rhGH może być niezbędna dla uzyskania ciąży [61, 62].

\subsection{Rozpoznawanie niedoboru hormonu wzrostu u osób dorostych}

Zasady diagnostyki niedoboru hormonu wzrostu po raz pierwszy opracowano w sposób kompleksowy w 1997 r. na konferencji zorganizowanej przez Towarzystwo Badań nad Hormonem Wzrostu (GRS, Growth Hormone Research Society) w Port Stephens w Australii [2], a następnie po 10 latach, to jest $w 2007 \mathrm{r}$., to samo Towarzystwo przedstawiło ich aktualizację wspólnie z Europejskim Towarzystwem Endokrynologii Pediatrycznej (ESPE, European Society for Pediatric Endocrinology), Towarzystwem Lawsona-Wilkinsa (Lawson Wilkins Society), Europejskim Towarzystwem Endokrynologicznym (ESE, European Society of Endocrinology) oraz Towarzystwami Endokrynologicznymi Japonii (Japan Endocrine Society) i Australii (Endocrine Society of Australia), na podstawie uzgodnień dokonanych podczas konferencji w Sydney w Australii [4].

W ramach powyższych uzgodnień poruszono następujące główne zagadnienia:

1. wyodrębniono grupy ryzyka pacjentów wymagających oceny wydzielania GH;

2. ustalono zasady wykonywania testów stymulacyjnych i ich standaryzacji;

3. ustalono zasady oznaczania biochemicznych markerów GH i ich interpretację;

4. przedstawiono zasady postępowania z pacjentami z GHD rozpoznanym w dzieciństwie, którzy zakończyli terapię promującą wzrastanie;

5. ustalono zasady dawkowania preparatów GH i monitorowania leczenia u osób dorosłych, z uwzględnieniem dodatkowych terapii hormonalnych stosowanych $\mathrm{u}$ tych pacjentów $\mathrm{w}$ przypadku wielohormonalnej niedoczynności przysadki oraz oceny bezpieczeństwa stosowanego leczenia.

W 2011 r. autorzy amerykańscy zaproponowali kolejną nowelizację tych zaleceń [63].

\subsubsection{Grupy ryzyka pacjentów z niedoborem hormonu wzrostu}

Zgodnie $\mathrm{z}$ aktualnymi rekomendacjami [4, 63] wyróżniono trzy grupy pacjentów wymagających oceny wydzielania GH:

1. Pacjenci $z$ udokumentowanymi nieprawidłowościami w obrębie osi podwzgórzowo-przysadkowej, z uwzględnieniem przyczyn hormonalnych, organicznych i/lub genetycznych.
2. Pacjenci po naświetlaniach czaszki lub leczeniu guzów wewnątrzczaszkowych.

3. Pacjenci po urazach czaszki lub krwawieniach podpajęczynówkowych (w tej grupie zalecana jest ocena wydzielania GH nie wcześniej niż po 12 miesiącach od urazu bądź krwawienia, ze względu na możliwość samoistnego powrotu prawidłowej czynności osi somatotropinowej).

W przypadku niejednoznacznych wyników testów należy kontynuować obserwację kliniczną i rozważyć powtórzenie diagnostyki. Nie ma wskazań do diagnostyki izolowanego GHD ujawniającego się de novo u osób dorosłych niespełniających żadnego z kryteriów wymienionych $w$ punktach $1-3$, natomiast $u$ około $25 \%$ pacjentów dorosłych ze zmianami organicznymi w okolicy przysadki lub po naświetlaniach GHD może być pierwszym stwierdzanym zaburzeniem czynności przysadki [4].

Konieczna jest również ponowna ocena wydzielania GH u młodzieży po osiągnięciu zakładanych celów terapii prowadzonej w dzieciństwie, to jest po zakończeniu procesu wzrastania i dojrzewania płciowego [64]. Nie jest natomiast rekomendowana kontynuacja terapii dawkami rhGH stosowanymi w celu promocji wzrastania (znacznie wyższymi niż stosowane po zakończeniu wzrastania) w momencie zwolnienia tempa wzrastania poniżej 2-2,5 cm/roki osiągnięcia wieku kostnego 16-17 lat dla chłopców i 14-15 lat dla dziewcząt [65]. Zgodnie z Charakterystyką Produktu Leczniczego Omnitrope "somatropiny nie wolno stosować do wspomagania wzrostu u dzieci ze skostniałymi nasadami kości" — dokument ten jednocześnie wskazuje, że „skostnieniu nasadowych płytek wzrostu" odpowiada osiągnięcie wieku kostnego $>14$ lat u dziewcząt i $>16$ lat u chłopców. Tym niemniej, zgodnie z aktualnym opisem Programu Lekowego dla dzieci z somatotropinową niedoczynnością przysadki, pacjenci z zaawansowaniem wieku kostnego w przedziale 16-18 lat dla chłopców i 14-16 lat dla dziewcząt nie spełniają kryteriów wyłączenia $z$ programu bez względu na tempo wzrastania, $w$ przeciwieństwie do pacjentów z mniej zaawansowanym wiekiem kostnym, u których wolne tempo wzrastania stanowi kryterium zakończenia terapii. Dostosowanie kryteriów zakończenia terapii promującej wzrastanie do aktualnych rekomendacji będzie skutkowało zwiększeniem puli pacjentów poniżej 18 roku życia, wymagających leczenia $\mathrm{w}$ obecnie opracowanym programie.

\subsubsection{Testy dynamiczne stymulujące wydzielanie hormonu wzrostu}

Rozpoznanie ciężkiego niedoboru hormonu wzrostu opiera się na stwierdzeniu objawów klinicznych GHD i zmniejszonego wydzielania GH (poniżej $3 \mathrm{ng} / \mathrm{ml}$ ) 
w testach stymulacyjnych po uprzednim wyrównaniu niedoborów kortyzolu, tyroksyny i steroidów płciowych, o ile takie niedobory występują [2, 4, 63].

Wykonanie testów stymulujących jest konieczne ze względu na:

- pulsacyjny rytm wydzielania $\mathrm{GH}$, uniemożliwiający prawidłową interpretację podstawowego stężenia GH w surowicy w oparciu o pojedynczy wynik;

— istnienie wielu czynników fizjologicznych pobudzających wydzielanie GH (sen, wysiłek fizyczny, stres psychiczny, poposiłkowy wzrost poziomu aminokwasów, względna hipoglikemia), jak również obniżających wydzielanie GH (hiperglikemia i podwyższony poziom wolnych kwasów tłuszczowych);

- zmienione wydzielanie GH w różnych stanach patologicznych:

- zwiększenie stężenia GH stwierdza się w akromegalii/gigantyzmie, stanach niedoborowych białka, głodzeniu, wyniszczeniu, jadłowstręcie psychicznym, przewlekłej niewydolności nerek, ektopowym wydzielaniu GHRH;

- obniżone stężenie GH stwierdza się w otyłości, niedoczynności tarczycy oraz nadczynności tarczycy.

Celem testów dynamicznych jest ocena wydzielania GH po zastosowaniu farmakologicznych czynników stymulujących.

W testach tych wykorzystuje się:

- bezpośrednie pobudzenia komórek somatrotropowych [po zastosowaniu somatoliberyny (GHRH, GH releasing hormone) bądź innych substancji wykazujących takie działanie, tzw. GH secretagogues - GHS] [66];

— wywołanie hipoglikemii bezwzględnej (po zastosowaniu insuliny);

- wywołanie hipoglikemii względnej (po zastosowaniu glukagonu);

- stymulację receptorów $\alpha$-adrenergicznych (po zastosowaniu klonidyny);

- hamowanie stymulacji receptorów $\beta$-adrenergicznych (po zastosowaniu propranololu);

- stymulację receptorów dopaminergicznych (po zastosowaniu preparatu L-DOPA, apomorfiny, bromokryptyny);

- inne mechanizmy.

Według rekomendacji z 2007 r., dla rozpoznania

GHD u osób dorosłych wystarczające jest wykonanie tylko jednego testu stymulacyjnego, przy czym nie jest konieczne wykonywanie testów u pacjentów z niedoborem co najmniej trzech innych hormonów przysadki oraz obniżonym stężeniem IGF-I w surowicy [4]. Jednak zarówno poprzednie rekomendacje z 1997 r. [2], jak i ostatnia aktualizacja z 2011 r. [63] sugerują, aby dla potwierdzenia rozpoznania izolowanego GHD u osoby dorosłej wymagane było wykonanie dwóch różnych testów stymulacyjnych.

U pacjentów z GHD rozpoznanym w dzieciństwie należy ocenić sekrecję GH po zakończeniu terapii promującej wzrastanie, po upływie co najmniej jednego miesiąca od podania ostatniej dawki preparatu rhGH, według tych samych zasad. Najnowsze doniesienia sugerują możliwość odstąpienia od wykonywania testów u chorych $\mathrm{z}$ niedoborem co najmniej trzech innych hormonów przedniego płata przysadki, u pacjentów z potwierdzonymi mutacjami genów kodujących czynniki transkrypcyjne, na przykład: POUF1 (Pit-1), PROP-1, HESX-1, LHX-3 i LHX-4 oraz z mutacjami prowadzącymi do izolowanego GHD (np. genu GH-1 czy genu receptora GHRH) oraz $\mathrm{w}$ przypadku zmian organicznych $\mathrm{w}$ okolicy podwzgórzowo-przysadkowej za wyjątkiem izolowanej ektopii tylnego płata przysadki lub hipoplazji płata przedniego $[4,63,65]$. W tych przypadkach za dostateczne potwierdzenie ciężkiego GHD uważa się obniżone stężenie IGF-I oznaczone po upływie co najmniej jednego miesiąca od zakończenia terapii rhGH [63]. W przypadku pacjentów ze zmianami strukturalnymi w okolicy podwzgórzowo-przysadkowej, jak również u osób po przebytej w dzieciństwie radioterapii, u których nie potwierdzono ciężkiego GHD po zakończeniu terapii promującej wzrastanie, należy rozważyć ponowną ocenę sekrecji GH po kilku latach z uwagi na możliwość późniejszego ujawnienia się ciężkiego niedoboru tego hormonu [65].

U osób dorosłych testem $\mathrm{z}$ wyboru jest test $\mathrm{z}$ zastosowaniem insuliny [4]. $U$ chorych z przeciwwskazaniami do testu insulinowego (choroba niedokrwienna serca, padaczka, podeszły wiek) należy zastosować testy alternatywne, z których za najbardziej wiarygodne uważa się łączone testy $\mathrm{z}$ argininą i GHRH $\mathrm{z}$ argininą i GHRP (GH releasing peptide) oraz test $\mathrm{z}$ glukagonem [4, 67]. Według zaleceń amerykańskich z 2011 r. [63] w diagnostyce GHD u osób dorosłych największą czułość i swoistość wykazuje test $\mathrm{z}$ insuliną oraz test z GHRH, natomiast w przypadku przeciwwskazań do testu insulinowego i/lub niedostępności GHRH można wykonać test $\mathrm{z}$ glukagonem.

Powyższe testy pozwalają na różnicowanie pomiędzy GHD a obniżeniem stężenia GH wynikającym bądź z fizjologicznie zmniejszonego wydzielania GH w okresie tak zwanej somatopauzy, bądź też z otyłości pacjenta. Należy jednak mieć na uwadze, że testy z wykorzystaniem GHRH oceniają jedynie maksymalną zdolność wydzielniczą przysadki, a nie funkcję całej osi somatotropinowej, a zatem mogą nie identyfikować pacjentów z zaburzeniami czynności podwzgórza [4]. U pacjentów po radioterapii czaszki oraz 
u chorych ze zmianami zapalnymi bądź naciekowymi w okolicy przysadki z prawidłowym wynikiem testu z GHRH zalecane jest dodatkowo wykonanie testu insulinowego. Ze względu na możliwość ujawnienia się GHD po wielu latach od radioterapii powinno się rozważyć powtórzenie testów w zależności od wskazań klinicznych [4].

Test $\mathrm{z}$ klonidyną, stosowany zwykle $\mathrm{w}$ diagnostyce GHD u dzieci, jak również test z L-DOPA, uważa się obecnie za nieprzydatne $u$ osób dorosłych, natomiast test $z$ argininą może być miarodajny jedynie $u$ młodzieży po zakończeniu terapii promującej wzrastanie [4].

Ustalono następujące punkty odcięcia dla rozpoznania ciężkiego GHD u osób dorosłych dla poszczególnych testów stymulacyjnych [4]:

- dla testu z insuliną i testu z glukagonem - 3,0 ng/ml;

- dla testu z GHRH i argininą: pacjenci z BMI poniżej

$25 \mathrm{~kg} / \mathrm{m}^{2}-11,0 \mathrm{ng} / \mathrm{ml}$, pacjenci z BMI $25-30 \mathrm{~kg} / \mathrm{m}^{2}$

$-8,0 \mathrm{ng} / \mathrm{ml}$, pacjenci z BMI powyżej $30 \mathrm{~kg} / \mathrm{m}^{2}$

$-4,0 \mathrm{ng} / \mathrm{ml}$.

U młodzieży z GHD rozpoznanym w dzieciństwie zaleca się w okresie po zakończeniu terapii promującej wzrastanie stosowanie wartości progowej dla testów $\mathrm{z}$ insuliną i glukagonem na poziomie $6,0 \mathrm{ng} / \mathrm{ml}$ oraz ponowną ocenę około 25 roku życia z zastosowaniem interpretacji testów stymulacyjnych jak u osób dorosłych, w celu ustalenia wskazań do kontynuacji terapii przez całe życie $[4,6]$.

Najczęściej stosowane testy stymulujące wydzielanie GH u osób dorosłych oraz u młodzieży po zakończeniu terapii promującej wzrastanie, mechanizm działania czynników stymulujących GH, sposób przeprowadzenia testów, objawy uboczne, przeciwwskazania i zalecane środki ostrożności przedstawiono w Załączniku 1.

\section{Metody oznaczania stężenia GH}

Do oznaczenia GH zaleca się stosowanie zestawów skalibrowanych wobec ludzkiego rekombinowanego hormonu wzrostu IRP 98/574, przy czym podkreślana jest celowość wypracowania uniwersalnych standardów oznaczeń oraz potrzeba walidacji używanych zestawów odczynników w odniesieniu do wykrywania różnych izoform $\mathrm{GH}$ oraz interferencje $\mathrm{z}$ białkiem wiążącym GH (GHBP, GH binding protein) [4].

\subsubsection{Biochemiczne markery działania hormonu wzrostu}

Insulinopodobny czynnik wzrostu I (IGF-I) jest obwodowym mediatorem działania hormonu wzrostu, a jego synteza jest kontrolowana przez GH. $\mathrm{W}$ organizmie istnieją dwie pule IGF-I: endokrynna i parakrynna. Miejscem syntezy puli endokrynnej jest głównie wątroba. W niektórych tkankach, jak na przykład w macicy, synteza IGF-I jest niezależna od $\mathrm{GH}$, natomiast jest regulowana przez estrogeny. $\mathrm{Na}$ miejscową syntezę IGF-I mogą wpływać także inne hormony, na przykład TSH na syntezę tego czynnika wzrostu w tarczycy. Działanie IGF-I jest wielokierunkowe i polega na pobudzaniu procesów wzrostowych komórek, ich migracji i procesów różnicowania się. IGF-I jest ważnym czynnikiem stymulującym syntazę tlenku azotu. Stwierdzono również korzystne działanie IGF-I na parametry układu sercowo-naczyniowego: zwiększenie kurczliwości mięśnia sercowego, obniżenie oporu naczyniowego i zwiększenie frakcji wyrzutowej serca. Ponadto wykazano, że IGF-I może działać jako czynnik antyapoptotyczny, ułatwiający przeżycie komórek. IGF-I jest czynnikiem nasilającym działanie gonadotropin na gonady.

Stężenie IGF-I oznacza się rano na czczo i porównuje otrzymane wartości z normami dla wieku i płci pacjenta, przy czym w piśmiennictwie podkreślana jest konieczność dopracowania zakresów referencyjnych dla populacji osób dorosłych, jak również standaryzacji metod oznaczeń [4].

Niskie stężenie IGF-I sugeruje niedobór GH przy wykluczeniu innych stanów mogących powodować jego obniżenie (niedożywienie, choroby wątroby, niewyrównana cukrzyca, niedoczynność tarczycy).

W aktualnych klasyfikacjach zaburzeń czynności osi somatotropinowej $\mathrm{u}$ dzieci GHD definiowany jest jako synonim wtórnego niedoboru IGF-I [68]. U osób dorosłych przyjmuje się jednak, że prawidłowe stężenie IGF-I nie wyklucza rozpoznania GHD [4].

Aktywność IGF-I modulują białka wiążące, a zwłaszcza IGFBP-3, którego synteza jest zależna od działania GH. Stężenie IGFBP-3 oznacza się rano na czczo, a stwierdzenie niskiego poziomu w surowicy jest uważane za mniej miarodajne niż niedobór IGF-I [27].

\subsection{Leczenie niedoboru hormonu wzrostu u osób dorostych}

\subsubsection{Wskazania do leczenia}

Wskazaniem do leczenia substytucyjnego u osób dorosłych jest stwierdzenie ciężkiego GHD. Celem leczenia jest spowodowanie ustąpienia niekorzystnych objawów klinicznych oraz wyrównanie zaburzeń metabolicznych związanych z GHD oraz poprawa jakości życia chorych $[2,4,44,63]$.

W odróżnieniu od GHD, obniżanie się poziomu GH w wieku starszym, będące najprawdopodobniej wynikiem fizjologicznych zmian $\mathrm{w}$ wydzielaniu neurohormonów regulujących sekrecję $\mathrm{GH}$, nie wymaga terapii. Tym niemniej, w przypadku pacjentów z ciężkim GHD zalecana jest kontynuacja terapii również $\mathrm{w}$ wieku podeszłym, ale z zastosowaniem niższych dawek rhGH [4]. 


\subsubsection{Przeciwwskazania do leczenia hormonem wzrostu}

Przeciwwskazaniami bezwzględnymi są [4, 27, 63, 69]:

- czynne procesy nowotworowe,

- ostre stany krytyczne.

U dzieci po przebyciu choroby nowotworowej, które otrzymują terapię rhGH, istnieje zwiększone ryzyko wystąpienia drugiego nowotworu [4]. Pomimo braku bezpośrednich dowodów na to, że leczenie substytucyjne rhGH zwiększa ryzyko wznowy nowotworów u osób dorosłych, należy mieć na uwadze istnienie korelacji pomiędzy podwyższonymi stężeniami IGF-I w surowicy i większym ryzykiem nowotworów złośliwych [63].

U chorych w stanach krytycznych wydzielanie GH kilkakrotnie wzrasta, szczególnie w przypadkach o niekorzystnym rokowaniu [70]. U osób dorosłych w stanach krytycznych (u pacjentów po zabiegach kardiochirurgicznych i operacjach brzusznych, po urazach wielonarządowych oraz $\mathrm{u}$ chorych $\mathrm{z}$ ostrą niewydolnością oddechową) stosowanie rhGH zwiększało śmiertelność, a u osób, które przeżyły, wydłużało okres stosowania wentylacji mechanicznej i przebywania w oddziale intensywnej terapii [71]. Pacjenci ci jednak otrzymywali wielokrotnie wyższe dawki rhGH niż jest to obecnie rekomendowane w leczeniu substytucyjnym u osób dorosłych.

Zgodnie z rekomendacjami z 1998 r. [2], do bezwzględnych przeciwwskazań do terapii rhGH zaliczano: czynne procesy nowotworowe, łagodne nadciśnienie śródczaszkowe, proliferacyjną i przedproliferacyjną retinopatię cukrzycową oraz drugi i trzeci trymestr ciąży.

Według aktualnych rekomendacji, chorzy z cukrzycą typu 2 mogą otrzymywać substytucję rhGH, ale wymagają wówczas odpowiedniego dostosowania leczenia cukrzycy [63]. Wystąpienie retinopatii może być związane $\mathrm{z}$ działaniem podwyższonych stężeń IGF-I, jak to ma miejsce u pacjentów z akromegalią [72]. U pacjentów z retinopatią cukrzycową leczonych rhGH odstawienie tego leczenia wiązało się ze zmniejszeniem nasilenia retinopatii $[73,74]$, nie stwierdzono natomiast związku pomiędzy leczeniem rhGH a wystąpieniem retinopatii (opublikowane badania dotyczyły dzieci, a nie osób dorosłych) [63, 75].

Łagodne nadciśnienie śródczaszkowe podczas terapii rhGH obserwowane jest rzadziej niż to wynikało z wcześniejszych doniesień $[63,76]$. U osób dorosłych opisano jedynie pojedyncze przypadki tego powikłania $[59,77]$. Obecnie przyjmuje się, że w przypadku wystąpienia wzrostu ciśnienia śródczaszkowego terapię rhGH należy przerwać, a jej wznowienie wymaga szczególnej ostrożności, zazwyczaj z zastosowaniem niższych dawek leku [65].
Ciężki GHD może być związany z obniżoną płodnością oraz powikłaniami we wczesnym okresie ciąży. Istnieją doniesienia, że stosowanie rhGH w okresie prekoncepcyjnym i we wczesnej ciąży może być korzystne. W prawidłowej ciąży pulsacyjna sekrecja GH ulega stopniowej supresji i jest zastępowana przez ciągłe wydzielanie łożyskowego GH, który jest głównym stymulatorem wydzielania IGF-I u ciężarnej. Wobec tego wydaje się uzasadniona kontynuacja terapii rhGH do momentu osiągnięcia dostatecznej syntezy GH w łożysku [78]. Tym niemniej, bezpieczeństwo stosowania rhGH w ciąży nie zostało dostatecznie udokumentowane i z tego względu terapia ta nie może być obecnie przedmiotem rekomendacji [62].

U osób w wieku podeszłym zaleca się zmniejszenie dawki rhGH, adekwatnie do fizjologicznego spadku wydzielania endogennego GH u osób zdrowych w tym okresie życia [4].

\subsubsection{Oczekiwane efekty leczenia}

Substytucyjne zastosowanie rhGH powoduje wyrównanie wszystkich zaburzeń związanych z niedoborem GH. Część zmian obserwuje się już po krótkotrwałym okresie leczenia, na wystąpienie innych trzeba czekać dłużej, zależnie od stopnia niedoboru GH, dawki rhGH oraz mechanizmu działania na poziomie poszczególnych tkanek [79].

U osób bezpośrednio po zakończeniu wrastania podstawowym celem stosowania rhGH jest uzyskanie pełnego rozwoju somatycznego, w tym optymalnej szczytowej masy kostnej i masy mięśniowej, a także zapobieganie pogorszeniu jakości życia $[4,6]$.

W przypadku rozpoczęcia terapii rhGH u osób dorosłych jej najważniejszymi celami są [4, 63, 80, 81]:

- poprawa składu ciała — zwiększenie beztłuszczowej masy ciała i zmniejszenie masy tłuszczowej, szczególnie w zakresie tkanki tłuszczowej trzewnej;

- zwiększenie wydolności wysiłkowej;

- zmniejszenie ryzyka osteoporozy i złamań wskutek korzystnego działania rhGH na kości, prowadzącego w warunkach długotrwałej (co najmniej 12-miesięcznej) terapii do przyrostu masy i gęstości mineralnej kości na skutek zwiększenia procesów odbudowy kości;

- zapobieganie wystąpieniu powikłań sercowo-naczyniowych wskutek korzystnego działania na gospodarkę lipidową (obniżenie poziomu cholesterolu całkowitego, frakcji LDL-cholesterolu i ApoB oraz wzrost poziomu frakcji HDL-cholesterolu i ApoE), funkcję śródbłonków, czynność mięśnia sercowego, a także obniżenie stężeń czynników prozapalnych i prokoagulacynych;

- poprawa jakości życia i funkcjonowania w sferze psychicznej. 


\subsubsection{Dawkowanie rhGH}

Dawkę GH należy dobierać indywidualnie, tak aby przy pełnej tolerancji leczenia, uzyskać jak najlepsze wyniki. Przy ustalaniu dawki początkowej należy mieć na uwadze, że wydzielanie GH jest wyższe u kobiet niż u mężczyzn, przy czym u obu płci jest ono najwyższe u osób młodych i obniża się z wiekiem. Proponowane wyjściowe dawki rhGH to $0,2 \mathrm{mg} / \mathrm{dziennie}$ dla młodych mężczyzn i $0,3 \mathrm{mg} /$ dziennie dla młodych kobiet, a 0,1 $\mathrm{mg} /$ dziennie dla osób starszych, natomiast u młodzieży z ciężkim GHD po zakończeniu terapii promującej wzrastanie zalecane są dawki pośrednie pomiędzy dawkami „pediatrycznymi” i stosowanymi u osób dorosłych [4].

Ustalanie dawki w przeliczeniu na metr kwadratowy powierzchni czy też na kilogram masy ciała u dorosłych pacjentów okazało się mało precyzyjne, z uwagi na różną wrażliwość osobniczą na hormon, a także różną szybkość wchłaniania się leku z tkanki podskórnej [2, 82] i nie jest obecnie rekomendowane [4].

W tym miejscu należy jeszcze raz dobitnie podkreślić, iż ile razy w obecnym dokumencie jest mowa o uzupełnianiu niedoboru $\mathrm{GH}$ u ludzi dorosłych, tyle razy autorzy mają na myśli uzupełnianie niedoboru GH do wartości referencyjnych dla danego wieku, a nie do wartości wyższych, na przykład do wartości stwierdzanych u ludzi młodych.

Przy ustalaniu wielkości optymalnej dawki hormonu wzrostu należy uwzględnić następujące czynniki:

\section{- Wiek pacjenta}

Wiadomo, że po zakończeniu wzrastania wydzielanie GH zmniejsza się fizjologicznie z wiekiem o około 14\% w każdej dekadzie życia [83] oraz równocześnie maleje stężenie IGF-I [84]. Dlatego zasadą powinno być takie dawkowanie rhGH, które zapewnia utrzymanie poziomu IGF-I w zakresie normy wiekowej (optymalnie, w górnym przedziale zakresu wartości referencyjnych dla wieku i płci) [4, 63]. Szczególną ostrożność należy zachować u pacjentów w wieku podeszłym.

\section{- Płeć pacjenta}

Zdrowe kobiety $\mathrm{w}$ okresie premenopauzalnym wydzielają $0,2 \mathrm{mg} \mathrm{GH}$ na dobę, podczas gdy mężczyźni w podobnym wieku $-0,1 \mathrm{mg} /$ dobę. Wychodząc z tego założenia, proponuje się rozpoczynanie leczenia rhGH od dawki 0,2 mg/dzień u mężczyzn i 0,3 mg/dzień u kobiet [4], przy czym konieczne jest ścisłe monitorowanie efektów metabolicznych działania rhGH, gdyż dawki te mogą okazać się niewystarczające, szczególnie u kobiet [85].

\section{- Równoczesne leczenie substytucyjne hydrokorty-} zonem lub L-tyroksyną

Sytuacja ta nakazuje szczególną ostrożność w ustalaniu dawki $\mathrm{GH}$. W pierwszym wypadku istnieje ryzyko obniżenia stężenia kortyzolu wskutek zmniejszenia aktywności 11ß-dehydrogenzay hydroksysteroidowej, co może prowadzić do konieczności zwiększenia dawki hydrokortyzonu u chorych już leczonych; w drugim - ze względu na zwiększenie konwersji tyroksyny do trijodotyroniny — może zwiększyć się zapotrzebowanie na L-tyroksynę u pacjentów już otrzymujących leczenie substytucyjne $[4,86]$. Należy również mieć na uwadze, że po włączeniu terapii rhGH może dojść do ujawnienia się wtórnej niedoczynności kory nadnerczy bądź wtórnej niedoczynności tarczycy.

\section{- Równoczesne stosowanie steroidów płciowych}

U kobiet otrzymujących preparaty steroidów płciowych, a zwłaszcza estrogeny podawane doustnie, zapotrzebowanie na rhGH może być zwiększone. Zalecany jest wybór innej drogi podania estrogenów oraz dostosowanie dawkowania rhGH po każdorazowej modyfikacji terapii estrogenowej [4, 63]. Stosowanie androgenów nie wiąże się z koniecznością modyfikacji terapii rhGH [4].

Hormon wzrostu podaje się raz dziennie wieczorem (w celu jak najlepszego naśladowania fizjologicznego rytmu sekrecji GH), w podskórnych wstrzyknięciach wykonywanych przy użyciu wstrzykiwaczy.

\subsubsection{Monitorowanie leczenia rhGH}

Kontrola leczenia powinna uwzględniać [2, 63]:

- wywiad z ukierunkowaniem na zachodzące zmiany komfortu życia, oceniane za pomocą wystandaryzowanego kwestionariusza jakości życia $(\mathrm{QoL}-$ Quality of Life) [87];

- badanie kliniczne (w tym określanie wskaźnika WHR i BMI, ciśnienie tętnicze krwi);

- określanie stężenia IGF-I w surowicy (początkowo co 1-2 miesiące, następnie co 6-12 miesięcy);

— ocenę stężenia glukozy lub hemoglobiny glikowanej (HbA1c) w surowicy raz w roku;

— określanie stężenia lipidów w surowicy raz w roku;

- ocenę składu masy ciała bioimpedancji elektrycznej co 6 miesięcy lub metodą absorpcjometrii rentgenowskiej co 12 miesięcy;

— ocenę gęstości mineralnej kości co 18-24 miesięcy [63];

- badania obrazowe ośrodkowego układu nerwowego (OUN) (rezonans magnetyczny, tomografia komputerowa), w zależności od potrzeb;

- ponowną ocenę zapotrzebowania na L-tyroksynę i/lub hydrokortyzon u pacjentów z wielohormonalną niedoczynnością przysadki oraz ocenę sekrecji L-tyroksyny i kortyzolu u pacjentów z wcześniej rozpoznanym izolowanym GHD w przypadku wystąpienia po włączeniu terapii rhGH objawów wskazujących na niedoczynność kory nadnerczy i/lub tarczycy;

- stosowanie ogólnie obowiązujących zasad profilaktyki nowotworów. 


\subsubsection{Objawy niepożądane i powikłania leczenia} substytucyjnego z zastosowaniem preparatów rhGH Objawy niepożądane leczenia są zazwyczaj łagodne, częściej występują u osób starszych oraz u osób o większej masie ciała, ich nasilenie jest proporcjonalne do dawki rhGH. Często objawy niepożądane zmniejszają swe nasilenie lub ustępują całkowicie po zredukowaniu dawki rhGH [2]. Rzadziej występują u ludzi dorosłych, którzy kontynuują leczenie rozpoczęte w dzieciństwie.

Najczęstsze objawy niepożądane:

- obrzęki z retencją płynów;

- bóle stawów i mięśni;

- nudności;

- sztywność mięśni;

— parestezje [44].

Sporadycznie opisywane objawy niepożądane:

- ginekomastia u starszych mężczyzn;

- zespół cieśni nadgarstka;

- bóle głowy z szumem w uszach;

- łagodne nadciśnienie śródczaszkowe;

- tarcza zastoinowa;

- nietolerancja glukozy, hiperinsulinemia oraz cukrzyca;

- nadciśnienie tętnicze $[2,63,88]$.

Najpoważniejsze obawy dotyczące bezpieczeństwa długoterminowej terapii substytucyjnej z zastosowaniem rhGH związane były z ryzykiem ewentualnego przerostu lewej komory serca, zwiększenia insulinooporności, a także wzrostu częstości występowania guzów złośliwych bądź nawrotów guzów przysadki. Jednakże dziesięcioletnie badania prospektywne nie wykazały występowania żadnego z tych powikłań [69]. Szczególną uwagę zwraca się na nowsze doniesienia, które również nie potwierdzają takich zależności $[89,90]$. W 2012 r. opublikowano dane wskazujące na zwiększoną śmiertelność osób dorosłych leczonych w dzieciństwie rhGH, zwłaszcza z zastosowaniem wyższych dawek tych preparatów, przy czym istotny statystycznie okazał się wzrost ryzyka zgonów z powodu guzów kości i krwawień śródczaszkowych, odnotowano także zwiększoną częstość zgonów w przebiegu kardiomiopatii i kardiomegalii [91]. Najnowsza metaanaliza z 2017 r. [92] nie potwierdziła zwiększonego ryzyka zgonu u dzieci i dorosłych leczonych rhGH. Nie ma również dowodów na to, że terapia rhGH zwiększa ryzyko nowotworów złośliwych, białaczek, innych nowotworów zlokalizowanych poza obrębem czaszki, a także wznowy nowotworów wewnątrzczaszkowych u pacjentów bez dodatkowych czynników ryzyka [92, 93]. Co więcej, analiza materiału zgromadzonego $\mathrm{w}$ bazie danych KIMS wykazała, że ryzyko zgonów w ciągu pierwszych 3 lat stosowania rhGH było wyższe $u$ pacjentów z niższymi stężeniami IGF-I podczas terapii [94].
Zwiększone jest jedynie ryzyko wystąpienia drugiego nowotworu, szczególnie u osób z CO-GHD oraz po przebytym napromienianiu OUN $[92,95,96]$. Nie ma też danych na to, że leczenie substytucyjne rhGH zwiększa ryzyko występowania raka jelita grubego, jak to ma miejsce $\mathrm{u}$ chorych na akromegalię [2]. Niemniej jednak zalecane powszechnie w całej populacji zasady profilaktyki i wczesnego wykrywania chorób nowotworowych odnoszą się tym bardziej do tej grupy pacjentów. Pacjenci po radioterapii guzów przysadki mają podwyższone ryzyko powikłań sercowo-naczyniowych, które jednak zmniejsza się podczas wieloletniej substytucji rhGH [80]. U dorosłych chorych leczonych rhGH odnotowano również zwiększoną częstość cukrzycy typu 2, wydaje się jednak, że jest ona związana przede wszystkim z obecnością innych współistniejących czynników ryzyka, a nie z samą terapią rhGH [92].

Doniesienia dotyczące powikłań terapii substytucyjnej z zastosowaniem rhGH znajdują się w bazach danych opracowanych przy udziale firm farmaceutycznych produkujących rhGH: KIMS (Pharmacia Corporation dawniej Pharmacia \& Upjohn), Nordireg (NovoNordisk), NCSS database (Genentech), HypoCCS (Eli Lilly). Największą liczbę pacjentów (ponad 16000 do momentu zamknięcia w 2012 r.) zgromadził w swej bazie program KIMS. W analizie obejmującej 14752 chorych leczonych rhGH w ramach programu KIMS w okresie do marca 2010 r. stwierdzono wystąpienie nowotworów złośliwych u 469 pacjentów (najczęściej były to nowotwory skóry w tym czerniak złośliwy u 87 osób, rak prostaty - u 77 mężczyzn, rak piersi u 34 kobiet) [96]. W bazie HypoCCS obejmującej dane 6840 osób dorosłych leczonych rhGH odnotowano 24 przypadki raka prostaty, 16 przypadków raka piersi, 15 przypadków czerniaka złośliwego, 11 przypadków raków kolorektalnych, 9 przypadków raka tarczycy i 9 przypadków glejaka. Ryzyko wystąpienia tych nowotworów było zbliżone do populacyjnego [96]. Dane zarówno z bazy KIMS, jak i HypoCCS nie wykazały zwiększonej częstości odrostów guzów przysadki i czaszkogardlaków w porównaniu z pacjentami nieotrzymującymi rhGH [97].

Chociaż bazy danych są doskonałym źródłem informacji, niezaprzeczalnie użytecznym w analizach populacyjnych, należy zauważyć, że nie spełniają kryteriów opracowań statystycznych. Częstość występowania powikłań w tych opracowaniach może być zafałszowana ze względu na rejestrowanie wszystkich dolegliwości i schorzeń, niezależnie od ich związku przyczynowego z terapią rhGH. Ponadto, pacjenci leczeni preparatami rhGH pozostają pod stałą, systematyczną opieką lekarską, co zwiększa możliwość wczesnego rozpoznania nowotworów i innych schorzeń. 
Zgodnie $\mathrm{z}$ aktualnym stanem wiedzy można przyjąć, że [97]:

— korzyści z leczenia substytucyjnego rhGH osób dorosłych przewyższają teoretyczne ryzyko wystąpienia u nich nowotworu złośliwego;

- przy zachowaniu zasad bezpieczeństwa dotyczących dawkowania rhGH i monitorowania terapii leczenie to nie zwiększa ryzyka wystąpienia de novo nowotworu złośliwego;

- pacjenci po przebytej $\mathrm{w}$ dzieciństwie chorobie nowotworowej mają zwiększone ryzyko wystąpienia wtórnych nowotworów;

- należy mieć na uwadze występowanie innych modyfikowalnych czynników ryzyka raka, takich jak otyłość, insulinooporność, siedzący tryb życia, zaburzenie rytmów dobowych, podwyższone stężenia czynników prozapalnych, stosowanie steroidów płciowych;

- dane dotyczące osób z dużym obciążeniem rodzinnym chorobami nowotworowymi oraz chorych w podeszłym wieku nie pozwalają na wyciagnięcie wniosków dotyczących bezpieczeństwa terapii w tych grupach pacjentów, stąd też wymagają oni szczególnie starannego monitorowania.

\subsubsection{Kryteria zaprzestania terapii}

Wydaje się, że substytucja GH, podobnie jak innych hormonów, powinna trwać od momentu rozpoznania przez całe życie pacjenta. Istnieją doniesienia na temat korzystnych efektów leczenia rozpoczętego po 65. roku życia [98]. U osób starszych, wraz z upływem czasu, należy zmniejszać dawkę hormonu wzrostu $[4,63,93]$.

Wskazaniem do zaprzestania leczenia powinno być:

- wystąpienie poważnych powikłań leczenia bądź przeciwwskazań do leczenia (wymienionych wcześniej);

— odrost guzów przysadki;

- brak efektów leczniczych, zwłaszcza w starszym wieku;

- brak zgody pacjenta na kontynuację terapii lub niestosowanie się do zaleceń dotyczących samego leczenia, wykonywania badań kontrolnych i modyfikacji stylu życia.

Na podstawie analizy danych z bazy KIMS zaproponowano ocenę punktową skuteczności leczenia rhGH w oparciu o oznaczenie stężenia cholesterolu całkowitego i IGF-I, pomiar obwodu talii oraz ocenę jakości życia na podstawie kwestionariusza QoL; opracowane zostały także modele predykcji, które mogą być wykorzystane przy podejmowaniu decyzji o kontynuacji leczenia [99]. Dokonując oceny skuteczności terapii rhGH w warunkach polskich, należy skorzystać z polskiej wersji kwestionariusza QoL-AGHDA, opracowanej przez Karbownik-Lewińską i wsp. [87].

\subsubsection{Zarejestrowane $w$ Polsce preparaty rhGH}

Obecnie stosuje się wyłącznie preparaty hormonu wzrostu uzyskane przez rekombinację DNA. Substancja czynna leku występuje albo w postaci gotowego roztworu, albo liofilizowanego proszku z dołączoną ampułką rozpuszczalnika. Rozpuszczalnik, zawierający środek konserwujący, zapewnia pełną aktywność leku w ciągu 2-3 tygodni po rozpuszczeniu, pod warunkiem przechowywania leku w temperaturze $2-8^{\circ} \mathrm{C}$. Podobne wymogi dotyczą przechowywania preparatów w postaci gotowych roztworów. Każda z firm produkuje również przystosowane do ich własnych preparatów wstrzykiwacze, ułatwiające dawkowanie i podawanie leku.

Obecnie w Polsce są zarejestrowane następujące preparaty rhGH:

1. Omnitrope (Sandoz),

2. Genotropin (Pfizer),

3. Norditropin (Novo Nordisk).

\section{Dotychczasowy model opieki zdrowotnej nad osobami dorosłymi z GHD w Polsce}

Dotychczas osoby dorosłe z GHD bez względu na jej etiopatogenezę nie były w Polsce w sposób skoordynowany ewidencjonowane, diagnozowane i leczone, jakkolwiek niewielka część tych pacjentów otrzymywała preparaty rhGH poza finansowaniem ze środków publicznych ( $w$ badaniach klinicznych bądź w trybie pełnopłatnego zakupu leku). Co więcej, nie była prowadzona świadoma profilaktyka schorzeń będących możliwymi powikłaniami niedoboru hormonu wzrostu ani wdrażana odpowiednia pomoc psychologiczna dla tej grupy chorych.

Niedobór GH u osób dorosłych był problemem niedostatecznie uświadamianym i niezbyt wnikliwie analizowanym $\mathrm{w}$ naszym społeczeństwie. Wynikało to $\mathrm{z}$ dotychczas powszechnego stereotypu myślenia, iż hormon wzrostu potrzebny jest $\mathrm{w}$ okresie wzrostu organizmu i przestaje mieć istotne znaczenie po jego zakończeniu.

W ciągu ostatnich kilkudziesięciu lat zagadnienie niedoboru GH u osób dorosłych znalazło się w centrum zainteresowań wielu wiodących ośrodków endokrynologicznych. Od ponad 30 lat w wielu krajach Europy i świata dorosłych pacjentów z GHD planowo leczy się preparatami rhGH, uzyskując poprawę stanu zdrowia i przeciwdziałając następstwom choroby. Przypadki leczenia rhGH dorosłych pacjentów z GHD w naszym kraju były dotychczas nieliczne, co wynika z braku odpowiednich standardów postępowania, jak również wysokiej ceny leku w przypadku zakupu indywidualnego. Brakuje jakichkolwiek opracowań dotyczących epidemiologii, etiologii oraz historii naturalnej GHD u osób dorosłych w Polsce. 


\section{Ogólnopolski Program Leczenia Niedoboru Hormonu Wzrostu u Osób Dorosłych oraz Młodzieży po zakończeniu Terapii Promującej Wzrastanie}

\subsection{Cele programu}

\subsubsection{Założenia ogólne}

Celem programu jest wdrożenie planowego, systematycznego, kontrolowanego leczenia GH osób dorosłych i młodzieży po zakończeniu terapii promującej wzrastanie z ciężkim GHD.

Zakłada się zarówno kontynuację leczenia młodzieży i osób dorosłych leczonych $\mathrm{w}$ dzieciństwie z powodu GHD, jak i rozpoczęcie terapii w przypadku rozpoznania GHD u osoby dorosłej, która uprzednio nie była leczona $\mathrm{z}$ tego powodu.

\subsubsection{Szczegółowe cele programu}

- Opracowanie przejrzystego schematu kwalifikacji do diagnostyki i postępowania diagnostycznego umożliwiającego prawidłowe, wczesne rozpoznanie GHD u ludzi dorosłych i młodzieży po zakończeniu terapii promującej wzrastanie.

- Opracowanie standardów postępowania kwalifikującego do leczenia rhGH.

- Opracowanie schematu postępowania terapeutycznego zgodnego ze standardami światowymi.

- Opracowanie zasad współpracy ośrodków opieki zdrowotnej na szczeblu podstawowym i specjalistycznym.

- Rozszerzenie składu Zespołu Koordynacyjnego ds. Stosowania Hormonu Wzrostu o osoby zajmujące się przede wszystkim terapią pacjentów dorosłych i młodzieży po zakończeniu terapii promującej wzrastanie, określenie ich zadań i zakresu obowiązków.

- Stworzenie centralnego rejestru pacjentów dorosłych zakwalifikowanych i leczonych rhGH.

- Zapewnienie refundowanego leczenia rhGH wszystkim osobom dorosłym oraz młodzieży po zakończeniu wzrastania wymagającym kontynuacji terapii substytucyjnej.

- Dokonanie centralnego zakupu i stworzenie systemu dystrybucji rhGH zapewniającego możliwie niską cenę leku dzięki planowanym, kontrolowanym zakupom hurtowym.

- Opracowanie danych dotyczących epidemiologii i etiopatogenezy GHD u ludzi dorosłych.

- Analiza danych pod kątem występowania objawów ubocznych, powikłań i niekorzystnych zdarzeń zaistniałych podczas trwania terapii.

- Opracowanie i analiza danych dotyczących korzyści zdrowotnych i ekonomicznych wynikających $\mathrm{z}$ wdrożenia terapii.

\subsection{Metody realizacji programu}

4.2.1. Zasady kierowania pacjentów $\mathrm{z}$ podejrzeniem GHD do specjalistycznych poradni endokrynologicznych

Do specjalistycznych poradni endokrynologicznych dla osób dorosłych będą kierowani wszyscy pacjenci z podejrzeniem niedoboru GH w celu obserwacji i diagnostyki w kierunku zaburzeń wydzielania hormonów przysadkowych. Ze względu na różnorodną etiologię choroby dorośli pacjenci z podejrzeniem GHD będą rekrutować się z różnych ośrodków opieki medycznej. Powinny to być następujące grupy pacjentów:

1. Pacjenci leczeni $w$ okresie dzieciństwa z powodu GHD, którzy ukończyli 18. rok życia po zakończeniu terapii promującej wzrastanie zostaną przekazani z ośrodka endokrynologii wieku rozwojowego do specjalistycznej poradni endokrynologicznej dla osób dorosłych wraz z "Kartą przeniesienia pacjenta leczonego rhGH z powodu niedoboru hormonu wzrostu z ośrodka endokrynologii wieku rozwojowego do Ośrodka Referencyjnego ds. Leczenia Hormonem Wzrostu Osób Dorosłych" (Załącznik 2), zawierającą pełną dokumentację dotyczącą dotychczasowej diagnostyki i przebiegu leczenia; po co najmniej 30 dniach od zaprzestania terapii rhGH nastąpi weryfikacja rozpoznania zgodnie z ustalonymi kryteriami i ewentualne ponowne wdrożenie terapii w Ośrodku Referencyjnym ds. Leczenia Hormonem Wzrostu Osób Dorosłych. W przypadku pacjentów kończących terapię promującą wzrastanie przed ukończeniem 18. roku życia ponowna ocena wydzielania GH i ewentualna kwalifikacja do dalszego stosowania rhGH zostanie dokonana w ośrodku prowadzącym dotychczasowe leczenie, a pacjenci będą przekazywani do Ośrodka Referencyjnego ds. Leczenia Hormonem Wzrostu Osób Dorosłych w wieku 18 lat.

2. Pacjenci ośrodków neurochirurgicznych po zabiegach z powodu gruczolaków przysadki lub innych guzów okolicy podwzgórzowo-przysadkowej (np. guzy typu craniopharyngioma).

3. Pacjenci ośrodków radioterapii po zabiegach radioterapii głowy.

4. Pacjenci ośrodków traumatologii po urazach głowy, u których występują objawy sugerujące GHD.

5. Osoby dorosłe zgłaszające się do poradni zdrowia psychicznego, psychologów, lekarzy neurologów czy psychiatrów, u których stwierdza się również somatyczne objawy sugerujące GHD.

6. Osoby dorosłe, u których lekarz rodzinny stwierdzi objawy sugerujące GHD, zwłaszcza gdy współistnieje ewentualna przyczyna niedoboru GH. 
W specjalistycznych poradniach endokrynologicznych dla osób dorosłych odbywać się będzie kwalifikacja pacjentów do hospitalizacji w wytypowanych Ośrodkach Referencyjnych ds. Leczenia Hormonem Wzrostu Osób Dorosłych w celu przeprowadzenia diagnostyki potwierdzającej bądź wykluczającej GHD.

\subsubsection{Ośrodki Referencyjne ds. Leczenia Hormonem Wzrostu Osób Dorosłych}

Hospitalizacja pacjentów zakwalifikowanych do diagnostyki odbywać się będzie w wyznaczonych referencyjnych klinikach i oddziałach endokrynologicznych dysponujących możliwością wykonania kompleksowych badań diagnostycznych: hormonalnych, obrazowych (w tym badania rezonansu magnetycznego ośrodkowego układu nerwowego) oraz opieki wielospecjalistycznej.

W trakcie hospitalizacji należy wykonać zalecane $\mathrm{w}$ standardach postępowania diagnostycznego badania potwierdzające lub wykluczające niedobór $\mathrm{GH}$ w warunkach wyrównania ewentualnych innych niedoborów hormonów przysadkowych w przypadku wielohormonalnej niedoczynności przysadki.

W przypadku rozpoznania somatotropinowej niedoczynności przysadki lekarz prowadzący powinien wypełnić „Wniosek o zakwalifikowanie do leczenia rhGH pacjenta z niedoborem hormonu wzrostu" (Załącznik 3) i przesłać go do rozpatrzenia Zespołowi Koordynacyjnemu.

Po zakwalifikowaniu pacjenta do leczenia GH w Ośrodku Referencyjnym ds. Leczenia Hormonem Wzrostu Osób Dorosłych odbywać się będą szkolenia pacjentów dotyczące sposobu przechowywania leku i podawania preparatu oraz ustalenie indywidualnego schematu leczenia i kontroli terapii.

Planowane jest stworzenie sieci Ośrodków Referencyjnych ds. Leczenia Hormonem Wzrostu Osób Dorosłych na bazie istniejących Klinik Endokrynologii zajmujących się leczeniem osób dorosłych w Polsce. Terapia pacjentów z ciężkim GHD, którzy zakończyli leczenie promujące wzrastanie przed ukończeniem 18. roku życia, będzie kontynuowana w ośrodkach pediatrycznych.

Obowiązkiem lekarza prowadzącego w Ośrodku Referencyjnym będzie przesyłanie do Zespołu Koordynacyjnego raz w roku „Karty obserwacji pacjenta leczonego rhGH z powodu niedoboru hormonu wzrostu" (Załącznik 4) dotyczącej stanu zdrowia pacjenta, wybranych parametrów auksologicznych, biochemicznych i hormonalnych, a także stosowanej dawki skutecznej w celu weryfikacji zapotrzebowania na lek.

\subsubsection{Zadania Zespołu Koordynacyjnego}

- Koordynacja i nadzór merytoryczny nad realizacją zadań programowych.
- Rozpatrywanie i zatwierdzanie „Wniosków o zakwalifikowanie do leczenia rhGH pacjenta $\mathrm{z}$ niedoborem hormonu wzrostu", nadzór merytoryczny nad prawidłową kwalifikacją pacjentów do leczenia.

- Opracowanie kryteriów wyłączania pacjentów $\mathrm{z}$ terapii.

- Stała weryfikacja centralnego zapotrzebowania na lek na podstawie analizy „Kart obserwacji pacjenta leczonego rhGH z powodu niedoboru hormonu wzrostu".

- Kontrola nad prawidłową dystrybucją leku.

- Stworzenie centralnego systemu rejestracji pacjentów.

- Organizacja i koordynacja działań edukacyjnych.

Zebrania Zespołu Koordynacyjnego odbywać się będą regularnie, nie rzadziej niż raz na trzy miesiące.

Dla celów realizacji programu niezbędne jest rozszerzenie składu Zespołu Koordynacyjnego ds. Stosowania Hormonu wzrostu o osoby, które będą zajmować się koordynacją leczenia GH pacjentów dorosłych i młodzieży z ciężkim GHD po zakończeniu terapii promującej wzrastanie. W szczególności planowane jest włączenie do Zespołu autorów niniejszego opracowania.

\subsection{Opracowanie szczegółowych wytycznych}

Szczegółowe wytyczne zostaną opracowane przy udziale wszystkich podmiotów zaangażowanych $\mathrm{w}$ realizację programu (przedstawiciele nadzoru specjalistycznego w zakresie endokrynologii, endokrynologii i diabetologii dziecięcej, pediatrii, medycyny rodzinnej oraz przedstawiciele środowisk akademickich: medycznych, psychologicznych, socjologicznych, ekonomicznych). Proponowany zakres procedur wykonywanych w ramach realizacji programu przedstawia Załącznik 5 .

\subsection{Materiaty edukacyjne i szkolenia}

Opracowane zostaną materiały edukacyjne dla lekarzy podstawowej opieki zdrowotnej oraz lekarzy specjalistów, przybliżające problem GHD u osób dorosłych. Omówione zostaną w nich możliwe przyczyny GHD, objawy sugerujące rozpoznanie GHD, podstawowe zagadnienia diagnostyki oraz korzyści płynące z leczenia substytucyjnego. Zostanie również przedstawiony sposób kierowania pacjenta podejrzanego o GHD do specjalistycznych poradni endokrynologicznej i Ośrodków Referencyjnych.

W okresie wdrażania programu planuje się przygotowanie serii wykładów dla lekarzy podstawowej opieki zdrowotnej i lekarzy specjalistów, poświęconych tematyce GHD u osób dorosłych.

$\mathrm{W}$ celu rozpowszechnienia wiedzy na temat choroby oraz podniesienia świadomości zdrowotnej społeczeństwa w tym zakresie planuje się przygotowanie broszur dla pacjentów oraz przeprowadzenie kampanii informacyjnej $\mathrm{w}$ środkach masowego przekazu (TV, radio, prasa, reklama). 


\subsection{Oczekiwane efekty wprowadzenia programu}

\subsubsection{Aspekt zdrowotny}

1. Wprowadzenie programu zakłada opracowanie i wdrożenie optymalnego algorytmu postępowania diagnostycznego i terapeutycznego osób dorosłych z GHD na obszarze całego kraju.

2. Prawidłowe leczenie pacjentów z GHD, zapobiegnie pogorszeniu jakości życia oraz innym odległym skutkom niedoboru hormonu wzrostu wymagającym często wieloletniej terapii i rehabilitacji pacjentów.

\subsubsection{Aspekt poznawczy}

1. Stworzenie centralnego rejestru dorosłych pacjentów z GHD pozwoli na opracowanie epidemiologii i etiopatogenezy tej jednostki chorobowej w Polsce oraz dokonanie wnikliwej analizy skuteczności terapii.

2. Realizacja zadań programu pogłębi wiedzę na temat GHD u ludzi dorosłych wśród lekarzy i pielęgniarek, jak również wpłynie na zwiększenie poziomu oświaty zdrowotnej w społeczeństwie w zakresie omawianego zagadnienia.

\subsubsection{Aspekt ekonomiczny}

1. Wprowadzenie programu pozwoli na:

- dokonywanie zakupów hurtowych leku, znacznie obniżając koszt transakcji;

- dokładne planowanie i prawidłową dystrybucję środków publicznych.

2. Prawidłowa terapia GHD umożliwi uniknięcie odległych skutków choroby, eliminując koszty wieloletniego leczenia i rehabilitacji (szczególnie w przypadku leczenia zawałów serca, złamań na tle osteoporozy), a także długotrwałego wyłączenia pacjenta z czynnego życia zawodowego.

3. Udowodniono, że koszty leczenia chorób będących powikłaniami GHD oraz koszty społeczne wynikające z wyłączenia pacjentów z czynnego życia zawodowego (zwolnienia lekarskie, renty chorobowe) przewyższają koszty stosowania preparatów rhGH w GHD u dorosłych. 


\section{Załącznik nr 1}

Najczęściej stosowane testy stymulujące wydzielanie hormonu wzrostu u ludzi dorosłych: mechanizm działania czynników stymulujących, sposób przeprowadzenia testu oraz objawy uboczne, przeciwwskazania i zalecane środki ostrożności

\begin{tabular}{|c|c|c|c|c|}
\hline $\begin{array}{l}\text { Czynnik } \\
\text { stymulujący }\end{array}$ & $\begin{array}{l}\text { Mechanizm działania czynnika } \\
\text { stymulującego }\end{array}$ & Dawka & $\begin{array}{l}\text { Czas pobierania } \\
\text { próbek (min) }\end{array}$ & $\begin{array}{l}\text { Objawy uboczne, zalecane środki } \\
\text { ostrożności, przeciwwskazania }\end{array}$ \\
\hline \multirow[t]{4}{*}{ Insulina } & \multirow[t]{4}{*}{$\begin{array}{l}\text { Insulina powoduje hipoglikemię, która } \\
\text { nasila wydzielanie hormonu wzrostu } \\
\text { (GH, growth hormone) pośrednio przez } \\
\text { stymulację hormonu uwalniającego hormon } \\
\text { wzrostu (GHRH, growth hormone-releasing } \\
\text { hormone) }\end{array}$} & \multirow[t]{4}{*}{$0,1 \mathrm{U} / \mathrm{kg}$ i.v. } & \multirow[t]{4}{*}{$\begin{array}{l}-30,0,30,60,90 \\
120 \text { (równoczasowo } \\
\text { pomiary glikemii) }\end{array}$} & $\begin{array}{l}\text { Pacjent musi mieć prawidłowe stężenie glukozy } \\
\text { w chwili rozpoczęcia testu. Podczas trwania } \\
\text { testu stężenie glukozy powinno osiągnąć } \\
\text { wartości poniżej } 40 \mathrm{mg} / \mathrm{dl} \text { lub poniżej } 50 \% \\
\text { wartości wyjściowej }\end{array}$ \\
\hline & & & & $\begin{array}{l}\text { Test jest przeciwwskazany u chorych } \\
\text { z padaczką, chorobami układu krążenia oraz } \\
\text { w starszym wieku }\end{array}$ \\
\hline & & & & $\begin{array}{l}\text { W czasie trwania testu należy monitorować } \\
\text { stężenie glukozy za pomocą glukometru. Należy } \\
\text { zapewnić stałą opiekę pielęgniarsko-lekarską } \\
\text { w czasie trwania testu }\end{array}$ \\
\hline & & & & $\begin{array}{l}\text { W przypadku znacznego nasilenia objawów } \\
\text { hipoglikemii należy doustnie podać glukozę } \\
\text { lub mocno osłodzony płyn. W przypadku } \\
\text { przedłużających się objawów hipoglikemii lub } \\
\text { wystąpienia zaburzeń świadomości należy } \\
\text { dożylnie podać roztwór glukozy } 10-25 \%\end{array}$ \\
\hline Glukagon & $\begin{array}{l}\text { Glukagon powoduje wzrost glikemii } \\
\text { stanowiący bodziec do wyrzutu endogennej } \\
\text { insuliny, która jest bodźcem do sekrecji GH } \\
\text { (patrz test z insuliną) }\end{array}$ & $\begin{array}{l}1 \mathrm{mg} \text { i.m. } \\
\text { (u dzieci } \\
30 \mu \mathrm{g} / \mathrm{kg} \\
\text { mc.) }\end{array}$ & $\begin{array}{l}0,90,120,150,180 \\
\text { (pomiary glikemii co } \\
30 \text { minut w czasie } \\
\text { całego testu) }\end{array}$ & $\begin{array}{l}\text { Podobne jak w teście z insuliną, ale zazwyczaj } \\
\text { występujące później i mniej nasilone }\end{array}$ \\
\hline L-DOPA & $\begin{array}{l}\text { Dopamina w warunkach podstawowych } \\
\text { stymuluje wydzielanie GH na poziomie } \\
\text { podwzgórza }\end{array}$ & $\begin{array}{l}500 \mathrm{mg} \\
\text { doustnie }\end{array}$ & $-30,0,30,60,90$ & $\begin{array}{l}\text { Objawy uboczne: często powoduje nudności } \\
\text { i wymioty }\end{array}$ \\
\hline Arginina & $\begin{array}{l}\text { Arginina stymuluje wydzielanie GH poprzez } \\
\text { oddziaływanie na ośrodki podwzgórzowe, } \\
\text { prawdopodobnie zmniejsza sekrecję } \\
\text { somatostatyny }\end{array}$ & $\begin{array}{l}0,5 \mathrm{~g} / \mathrm{kg} \text { i. } . \\
\text { przez } 30 \mathrm{~min} \\
\text { (maks. } 30 \mathrm{~g} \text { ) }\end{array}$ & $\begin{array}{l}-30,0,30,60,90 \\
120\end{array}$ & $\begin{array}{l}\text { Objawy uboczne: może powodować nudności } \\
\text { i wymioty i podrażnienie w miejscu podania. } \\
\text { Przeciwwskazania: ciężkie choroby wątroby, } \\
\text { nerek i kwasica }\end{array}$ \\
\hline GHRH & $\begin{array}{l}\text { Bezpośrednio stymuluje przysadkę do } \\
\text { wydzielania GH. Może być wykorzystywany } \\
\text { do różnicowania niedoboru GH pochodzenia } \\
\text { przysadkowego i podwzgórzowego }\end{array}$ & $\begin{array}{l}1 \mu \mathrm{g} / \mathrm{kg} \mathrm{w} \\
\text { szybkim } \\
\text { podaniu } \\
\text { dożylnym }\end{array}$ & $-30,-15,0,30,60$ & $\begin{array}{l}\text { Objawy uboczne: uderzenia gorąca, } \\
\text { metaliczny smak lub zapach }\end{array}$ \\
\hline
\end{tabular}

\section{Załącznik nr 2}

Pieczęć ośrodka wystawiającego wniosek:

\section{KARTA PRZENIESIENIA PACJENTA LECZONEGO RHGH Z POWODU NIEDOBORU HORMONU WZROSTU Z OŚRODKA ENDOKRYNOLOGII WIEKU ROZWOJOWEGO DO OŚRODKA REFERENCYJNEGO DS. LECZENIA HORMONEM WZROSTU LUDZI DOROSEYCH}

\section{Dane personalne pacjenta}

Nazwisko i imię pacjenta:

Miejsce zamieszkania pacjenta:

Miejscowość: $\mathrm{Nr}$ Kod Poczta

ul. Nr domu Nr mieszkania

Województwo:

Telefon kontaktowy: 


\section{Przynależność do Oddziału NFZ: $\square \square \square$}

Data urodzenia: $\square \square$ - $\square \square-\square \square \square \square$ dzień - miesiąc - rok PESEL $\square \square \square \square \square \square \square \square \square \square \square$

Pochodzenie etniczne:

$\mathrm{K}$ - kaukaskie I - inne, jakie

Płeć:

$$
\text { K- kobieta } \quad \mathrm{M} \text { - mężczyzna }
$$

\section{Wywiad}

a) Dane okołoporodowe:

masa ciała przy urodzeniu: $\square \square \square \square \mathrm{g} \quad$ długość ciała przy urodzeniu: $\square \square, \square \mathrm{cm}$ obwód głowy: $\square \square, \square$ cm

który poród: $\square \square$ która ciąża: $\square \square \quad$ czas trwania ciąży w tyg: $\square \square$

przebieg ciąży prawidłowy: $\square \mathrm{T}$ - tak, $\mathrm{N}$ - nie, jeśli nie, opisz

przebieg porodu: drogami natury $\square$, główkowy $\square$, pośladkowy $\square$, inny

cięcie cesarskie $\square$, poród kleszczowy $\square$, inny

uraz porodowy $\square$, niedotlenienie i reanimacja $\square$

ocena wg skali Apgar $\square$

przebieg okresu noworodkowego prawidłowy: $\square \mathrm{T}$ - tak, $\mathrm{N}$ - nie

Jeśli nie, opisz

b) Wywiad dotyczący dojrzewania płciowego:

Jeśli mężczyzna:

Początek dojrzewania płciowego: $\square$ wczesny $\quad \square$ przeciętny $\quad \square$ późny

$\square$ spontaniczny

$\square$ indukowany

Jeśli kobieta:

Wystąpienie pierwszego krwawienia miesięcznego (menarche): wiek $\square \square$ lat

$\square$ spontaniczne $\square$ indukowane

c) Wywiad rodzinny:

$\begin{array}{lrr}\text { matka: } & \text { wzrost } \square \square \square, \square \text { cm } & \text { masa ciała } \square \square \square, \square \text { kg } \\ \text { ojciec: } & \text { wzrost } \square \square \square, \square \text { cm } & \text { masa ciała } \square \square \square, \square \text { kg } \\ \text { wzrost docelowy (TH) } \square \square \square, \square \text { cm } & \text { SDS TH ( } \square \square, \square \square \text { ) }\end{array}$

d) Choroby przewlekłe:

$\begin{array}{lll}\text { cukrzyca } & \square & \mathrm{T}-\text { tak, } \mathrm{N}-\text { nie } \\ \text { białaczka } & \square & \mathrm{T}-\text { tak, } \mathrm{N}-\text { nie } \\ \text { naświetlania } & \square & \mathrm{T}-\text { tak, } \mathrm{N}-\text { nie } \\ \text { leki cytostatyczne } & \square & \mathrm{T}-\text { tak, } \mathrm{N}-\text { nie } \\ \text { inne } & \square & \mathrm{T}-\text { tak, } \mathrm{N}-\text { nie }\end{array}$

3. Dane dotyczące diagnostyki niedoboru hormonu wzrostu (GHD)

rok rozpoznania niedoboru hormonu wzrostu $\square \square \square \square$

Jeśli przyczyna organiczna:

rodzaj guza opis

zabieg neurochirurgiczny opis

radioterapia opis

leki cytostatyczne opis

Postać niedoczynności przysadki:

izolowany niedobór GH

niedobór TSH

wielohormonalna

rok rozpoznania

$\square \mathrm{T}$ - tak, $\mathrm{N}$ - nie

niedobór ACTH

$\square \square \square \square \quad$ substytucja: $\square \mathrm{T}-\mathrm{tak}, \mathrm{N}-$ nie

rok rozpoznania

$\square \mathrm{T}$ - tak, $\mathrm{N}$ - nie substytucja: $\square \mathrm{T}$ - tak, $\mathrm{N}$ - nie 


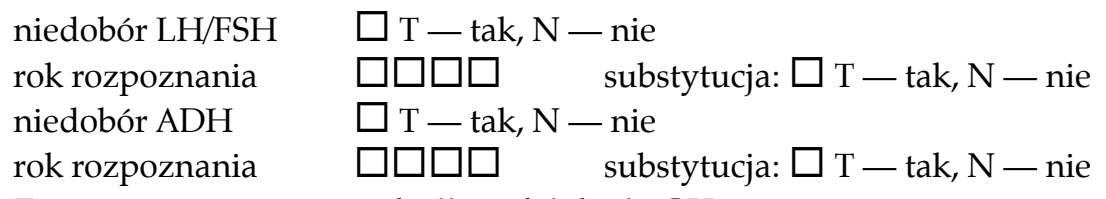

Zastosowane testy stymulacji wydzielania GH:

Data $\square \square-\square \square-\square \square \square \square$

sposób stymulacji

.maks. stężenie GH

$\square \square, \square \quad$ jedn

Data $\square \square-\square \square-\square \square \square \square$

sposób stymulacji .maks. stężenie GH

$\square \square, \square \quad$ jedn.

Data $\square \square-\square \square-\square \square \square \square$

sposób stymulacji ..... .maks. stężenie GH

$\square \square, \square \quad$ jedn.

Data $\square \square-\square \square-\square \square \square \square$

profil dobowy/nocny $\mathrm{GH}$.

maks. stężenie GH

$\square \square, \square$

jedn. .........

jedn. .........

średnie stężenie GH $\square \square, \square$

Data $\square \square$ - $\square \square$ - $\square \square \square \square$ Stężenie IGF-I w surowicy: wartość $\square \square \square \square, \square \quad$ jedn.

zakres wartości referencyjnych ................

Data $\square \square$ - $\square \square-\square \square \square \square$ Stężenie IGFBP-3 w surowicy: wartość $\square \square \square \square$, $\square$ jedn.

zakres wartości referencyjnych

Badanie MR okolicy podwzgórzowo-przysadkowej

Data badania $\square \square-\square \square-\square \square \square \square$

Badanie TK okolicy podwzgórzowo-przysadkowej

Data badania $\square \square-\square \square-\square \square \square$

\section{Ustalone rozpoznanie:}

1

2

3

4. Dane dotyczące terapii hormonem wzrostu

Data rozpoczęcia terapii $\square \square-\square \square-\square \square \square \square$

przebieg terapii bez powikłań $\square \mathrm{T}$ - tak, $\mathrm{N}$ - nie

Jeśli nie, opisz

\section{Data ostatniej iniekcji $\square \square-\square \square-\square \square \square \square$}

\section{Główny powód zaprzestania leczenia:}

spełnione kryteria wyłączenia z programu lekowego dla dzieci

uzyskanie prawidłowego wzrostu

zarośnięcie nasad kostnych

znaczne zwolnienie tempa wzrastania

zmiana diagnozy

decyzja pacjenta

inne

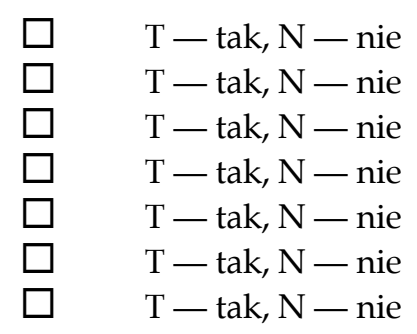

5. Dane auksologiczne po zakończeniu terapii: data badania $\square \square-\square \square-\square \square \square \square$ wzrost $\square \square \square, \square$ cm $\quad$ masa ciała $\square \square \square, \square$ kg $\quad$ BMI $\square \square, \square$ kg/m² $\quad$ WHR $\square \square \square$ Badanie psychologiczne przeprowadzone po zakończeniu leczenia: $\square \mathrm{T}$ — tak, $\mathrm{N}$ — nie Jeśli tak, opisz 
Test psychologiczny oceny jakości życia (test QoL-AGRDA)

Inne:

6. Badania laboratoryjne wykonane po zakończeniu leczenia:

testy stymulacyjne na wydzielanie GH

data $\square \square-\square \square-\square \square \square \square$ sposób stymulacji maks. GH $\square \square, \square$ jedn. data $\square \square-\square \square-\square \square \square \square$ sposób stymulacji maks. GH $\square \square, \square$ jedn.

Przy teście z insuliną proszę podać wartość wyjściową i minimalną glikemii wartość $\square \square \square \square, \square$ jedn. .............., wartość $\square \square \square \square, \square$ jedn. .............. Stężenie IGF-I w surowicy: data $\square \square$ - $\square \square$ - $\square \square \square \square$ wartość $\square \square \square \square$, $\square$ jedn. zakres wartości referencyjnych

Stężenie IGFBP-3 w surowicy: data $\square \square-\square \square-\square \square \square \square$ wartość $\square \square \square \square \square$ jedn. zakres wartości referencyjnych

Badanie densytometryczne data $\square \square-\square \square-\square \square \square \square$

Metoda:

\begin{tabular}{l|l|l|l|l|l}
\hline & Z-score & T-score & BMD [g/cm] & BMC [kg] & Uwagi \\
\hline Odcinek lędźwiowy kręgosłupa & & & & & \\
\hline Szyjka kości udowej & & & & & \\
\hline Badanie kośćca całego ciała & & & & & \\
\hline Inne & & & & & \\
\hline Inne & & & & & \\
\hline
\end{tabular}

Inne:

\section{Jednostka wypełniająca wniosek:}

Pełna nazwa:

Adres:

Telefon/fax:

Data wystawienia wniosku: $\square \square-\square \square-\square \square \square \square$

Lekarz wystawiający wniosek:

Imię:

Podpis i pieczątka:

Nazwisko:

Kierownik/Ordynator jednostki wystawiającej wniosek: Podpis i pieczątka:

\section{Załącznik nr 3}

Pieczęć ośrodka wystawiającego wniosek:

\section{WNIOSEK O ZAKWALIFIKOWANIE DO LECZENIA rhGH PACJENTA Z NIEDOBOREM HORMONU WZROSTU}

1. Dane personalne pacjenta

Nazwisko i imię pacjenta:

Miejsce zamieszkania pacjenta:

Miejscowość: $\mathrm{Nr}$. Kod Poczta

ul.

$\mathrm{Nr}$ domu

Nr mieszkania

Województwo:

Telefon kontaktowy: 


\section{Przynależność do Oddziału NFZ: $\square \square \square$}
Data urodzenia: $\square \square-\square \square-\square \square \square \square$ dzień - miesiąc - rok PESEL $\square \square \square \square \square \square \square \square \square \square \square$
Pochodzenie etniczne:
$\mathrm{K}$ - kaukaskie I - inne, jakie
Płeć:

$$
\text { K- kobieta } \quad \mathrm{M} \text { - mężczyzna }
$$

\section{Aktywność zawodowa pacjenta:}
$\square$ uczeń/student
$\square$ pracuje umysłowo
$\square$ pracuje fizycznie
$\square$ jest rolnikiem
$\square$ jest na rencie
$\square$ jest na emeryturze

\section{Stan cywilny:}
$\square$ panna/kawaler
$\square$ zamężna/żonaty
$\square$ rozwiedziona/rozwiedziony
$\square$ wdowa/wdowiec
Liczba dzieci

\section{Czy pacjent pali papierosy:}

$\square$ nie pali w ogóle

$\square$ pali czasami

$\square$ pali mniej niż 15 papierosów dziennie

$\square$ pali więcej niż 15 papierosów dziennie

\section{Wywiad dotyczący dojrzewania płciowego:}

Jeśli mężczyzna:

Początek dojrzewania płciowego: $\square$ wczesny $\quad \square$ przeciętny $\quad \square$ późny

$\square$ spontaniczny

$\square$ indukowany

Jeśli kobieta:

Wystąpienie pierwszego krwawienia miesięcznego (menarche): wiek $\square \square$ lat

$\square$ spontaniczne $\square$ indukowane

Wiek wystąpienia menopauzy/zaprzestania miesiączkowania: $\square \square$ lata

\section{Wywiad dotyczący stanu zdrowia pacjenta:}

Czy u pacjenta rozpoznano:

$\square$ nadciśnienie tętnicze

rok rozpoznania $\square \square \square \square$

$\square$ chorobę niedokrwienną serca

rok rozpoznania $\square \square \square \square$

$\square$ zawał serca

rok rozpoznania $\square \square \square \square$

$\square$ zwyrodnienie stawów

rok rozpoznania $\square \square \square \square$

$\square$ cukrzycę

rok rozpoznania $\square \square \square \square$

$\square$ nowotwory (inne niż przysadki)

rok rozpoznania $\square \square \square \square$

opis

rok rozpoznania $\square \square \square \square$

opis

$\begin{array}{ll}\square \text { złamania kości } & \text { rok rozpoznania } \square \square \square \square \text { lokalizacja. } \\ & \text { rok rozpoznania } \square \square \square \square \text { lokalizacja. } \\ & \text { rok rozpoznania } \square \square \square \square \text { lokalizacja. }\end{array}$

Inne choroby przewlekłe: $\quad \square \mathrm{T}$ - tak; $\mathrm{N}$ - nie

Jeśli tak, opisz 


\section{Istotny wywiad rodzinny:}

Czy w najbliższej rodzinie (rodzice lub rodzeństwo) rozpoznano:

choroby naczyń i serca

złamania kości biodrowej

nowotwory

łagodne

złośliwe $\square \quad \mathrm{T}$ - tak; $\mathrm{N}$ - nie; B - brak danych

$\square \quad \mathrm{T}$ - tak; $\mathrm{N}$ - nie; $\mathrm{B}$ - brak danych

$\square \quad \mathrm{T}$ - tak; $\mathrm{N}$ - nie; B - brak danych $\square \quad \mathrm{T}$ - tak; $\mathrm{N}$ - nie; $\mathrm{B}$ - brak danych

$\mathrm{T}$ - tak; $\mathrm{N}$ - nie; $\mathrm{B}$ - brak danych

\section{Wywiad dotyczący niedoboru hormonu wzrostu:}

Rok rozpoznania niedoboru hormonu wzrostu $\square \square \square \square$ rok

Pierwotna przyczyna niedoboru hormonu wzrostu:

$\square$ guz przysadki lub jego leczenie

rodzaj guza przysadki: $\quad \square$ nieczynny hormonalnie

$\square$ wydzielający GH

$\square$ wydzielający gonadotropiny

$\square$ nieznany

$\square$ czaszkogardlak

$\square$ zabiegi chirurgiczne (inne niż zabiegi chirurgiczne przysadki)

$\square$ naświetlania (inne niż naświetlania przysadki)

$\square$ idiopatyczne

$\square$ urazy

$\square$ inne, jakie

Czy z powodu zaburzeń przysadki pacjent był leczony chirurgicznie? $\square \mathrm{T}$ - tak; $\mathrm{N}$ - nie Jeśli tak, podaj liczbę zabiegów:

Dane szczegółowe dotyczące trzech ostatnich operacji:

rok $\quad \square \square \square \square \quad$ rok $\square \square \square \square \quad$ rok

Typ operacji: przezskroniowa
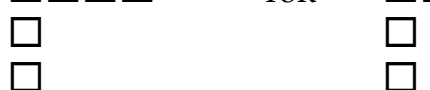

wydzielający ACTH

$\square$ wydzielający prolaktynę

$\square$ wydzielający TSH

z dostępu przez zatokę klinową

Czy z powodu zaburzeń przysadki pacjent był leczony radioterapią:

zewnętrzną:

stereotaktyczną: rok $\square \square \square \square$

rok $\square \square \square \square$

\section{Obecny stan kliniczny:}

Badanie podmiotowe:

Główne dolegliwości:

$\square$ osłabienie, $\square$ łatwa męczliwość, $\square$ uczucie stałego zmęczenia

$\square$ obniżenie nastroju, $\square$ zmniejszenie energii życiowej

$\square$ pogorszenie kontaktów społecznych z nasiloną tendencją do izolacji

$\square$ zaburzenie reakcji emocjonalnych, $\square$ poczucie pogorszenia jakości życia

$\square$ brak poczucia zdrowia

Inne, opisz

Badanie psychologiczne:

Test psychologiczny oceny jakości życia (test QoL-AGHDA)

Inne:

Badanie przedmiotowe:

Wzrost: $\square \square \square, \square$ cm

Masa ciała: $\square \square \square \mathrm{kg}$

BMI $\square \square, \square \mathrm{kg} / \mathrm{m}^{2}$ 
Obwód talii: $\square \square \square \mathrm{cm} \quad$ Obwód bioder: $\square \square \square \mathrm{cm} \quad$ WHR $\square \square, \square$

Ciśnienie tętnicze krwi: $\square \square \square / \square \square \square \mathrm{mmHg}$

Częstość tonów serca: $\square \square \square / \mathrm{min}$

Odchylenia od stanu prawidłowego:

Głowa:

Szyja:

Klatka piersiowa:

Układ krążenia:

Układ oddechowy:

Brzuch:

Układ nerwowy:

Narządy płciowe:

Inne:

\section{Badania dodatkowe:}

Testy stymulacyjne na wydzielanie GH

data $\square \square-\square \square-\square \square \square \square$ sposób stymulacji ........ maks. GH $\square \square, \square$ jedn.......

data $\square \square-\square \square-\square \square \square \square$ sposób stymulacji ........ maks. GH $\square \square, \square$ jedn.......

Przy teście z insuliną proszę podać wartość wyjściową i minimalną glikemii wartość $\square \square \square \square, \square$ jedn. .............., wartość $\square \square \square \square, \square$ jedn. .............
data $\square \square-\square \square-\square \square \square \square$
$\square$ profil dobowy
maks. GH
$\square \square, \square$ jedn. ......

średnie stężenie GH $\square \square, \square$ jedn......

Czy rozpoznano niedobór innych hormonów przysadkowych: ( $\mathrm{T}$ - tak; $\mathrm{N}-$ nie)

$\square$ niedobór TSH

$\square$ niedobór ACTH

$\square$ niedobór LH/FSH

rok rozpoznania $\square \square \square \square$

rok rozpoznania $\square \square \square \square$

rok rozpoznania $\square \square \square \square$

$\square$ terapia substytucyjna

$\square$ niedobór ADH rok rozpoznania $\square \square \square \square$

$\square$ terapia substytucyjna

$\square$ terapia substytucyjna

$\square$ terapia substytucyjna

\section{Aktualne wyniki badań:}

\begin{tabular}{|c|c|c|c|c|}
\hline Badanie & Data & Wartość & Jednostki & Zakres normy \\
\hline \multicolumn{5}{|l|}{ TSH } \\
\hline \multicolumn{5}{|l|}{$\mathrm{FT}_{4}$} \\
\hline \multicolumn{5}{|l|}{$\mathrm{FT}_{3}$} \\
\hline \multicolumn{5}{|l|}{ Kortyzol } \\
\hline \multicolumn{5}{|l|}{ ACTH } \\
\hline \multicolumn{5}{|l|}{$\mathrm{Prl}$} \\
\hline \multicolumn{5}{|l|}{ LH } \\
\hline \multicolumn{5}{|l|}{ FSH } \\
\hline \multicolumn{5}{|l|}{ IGF-I } \\
\hline \multicolumn{5}{|l|}{ IGFBP-3 } \\
\hline \multicolumn{5}{|l|}{ Stężenie glukozy w surowicy } \\
\hline Stężenie hemoglobiny glikowanej & & & & \\
\hline
\end{tabular}

Badania dotyczące funkcji nerek

Badania dotyczące funkcji wątroby

\section{Lipidogram:}

\begin{tabular}{l|l|l|l|l}
\hline Badanie & Data & Wartość & Jednostki & Zakres normy \\
\hline Cholesterol całkowity & & & & \\
\hline Frakcja LDL-cholesterolu & & & & \\
\hline Frakcja HDL-cholesterolu & & & & \\
\hline Triglicerydy & & & & \\
\hline Lp (a) & & & & \\
\hline
\end{tabular}


Badanie densytometryczne:

data badania $\square \square-\square \square-\square \square \square \square$

Metoda:

\begin{tabular}{l|l|l|l|l|l}
\hline & Z-score & T-score & BMD [g/cm] & BMC [kg] & Uwagi \\
\hline Odcinek lędźwiowy kręgosłupa & & & & & \\
\hline Szyjka kości udowej & & & & & \\
\hline Badanie kośćca całego ciała & & & & & \\
\hline Inne & & & & & \\
\hline Inne & & & & & \\
\hline
\end{tabular}

Ocena składu masy ciała

Elektrokardiogram spoczynkowy

Próba wysiłkowa

Badanie echokardiograficzne

Badanie MR lub badanie TK wykonane w ciągu ostatnich 6 miesięcy

$\square \mathrm{T}$ - tak; $\mathrm{N}$ - nie

Jeśli tak, opisz

Inne:

\section{Czy kiedykolwiek wcześniej stosowano terapię substytucyjną rhGH?}

$\square \mathrm{T}$ - tak; $\mathrm{N}$ - nie

Jeśli tak, czy w dzieciństwie (childhood-onset GHD)?

$\square \mathrm{T}$ - tak; $\mathrm{N}-$ nie

czy po ukończeniu 18 rż. (adult-onset GHD)?

$\square$ T - tak; $N$ - nie

Jeśli w dzieciństwie:

Data rozpoczęcia leczenia rhGH $\square \square$ - $\square \square \square \square$ miesiąc — rok

Data zaprzestania leczenia rhGH $\square \square$ - $\square \square \square \square$ miesiąc — rok

Czy wystąpiły powikłania podczas leczenia rhGH? $\quad \square \mathrm{T}-$ tak; $\mathrm{N}$ - nie

Jeśli tak, wymień 
Jeśli po ukończeniu 18 r.ż:

Początek leczenia $\quad \square \square-\square \square \square \square$ miesiąc — rok

Czas trwania leczenia $\square \square$ miesiące

Czy pacjent nadal jest leczony? $\square \mathrm{T}-$ tak; $\mathrm{N}-$ nie

Jeśli nie, podaj datę ostatniej iniekcji $\square \square-\square \square \square \square$ miesiąc — rok

Jeśli tak, podaj dokładną datę rozpoczęcia obecnego okresu leczenia:

$\square \square-\square \square-\square \square \square \square$ dzień - miesiąc - rok

Czy wystąpiły powikłania podczas leczenia rhGH? $\quad \square \mathrm{T}$ - tak; $\mathrm{N}$ - nie

Jeśli tak, opisz

\section{Wymień leki aktualnie stosowane przez pacjenta:}

Nazwa leku dawka początek stosowania $\square \square-\square \square \square \square$ m-r

Nazwa leku dawka początek stosowania $\square \square-\square \square \square \square$ m-r

Nazwa leku dawka początek stosowania $\square \square-\square \square \square \square$ m-r

Nazwa leku dawka początek stosowania $\square \square-\square \square \square \square$ m-r

Nazwa leku dawka początek stosowania $\square \square-\square \square \square \square$ m-r

Nazwa leku dawka początek stosowania $\square \square-\square \square \square \square$ m-r

\section{Uwagi:}

Jednostka wypełniająca wniosek:

Data wystawienia wniosku: $\square \square-\square \square-\square \square \square \square$

Pełna nazwa:

Adres:

Telefon/fax:

Lekarz wystawiający wniosek:

Imię i nazwisko

Podpis i pieczątka

Kierownik/Ordynator jednostki wystawiającej wniosek:

Podpis i pieczątka:

\section{Załącznik nr 4}

Pieczęć ośrodka wystawiającego wniosek:

\section{KARTA OBSERWACJI PACJENTA LECZONEGO rhGH Z POWODU NIEDOBORU HORMONU WZROSTU}

(wypełniać co 12 miesięcy)

1. Dane personalne pacjenta:

Nazwisko i imię pacjenta:

Data urodzenia: $\square \square-\square \square-\square \square \square \square$ dzień — miesiąc — rok PESEL $\square \square \square \square \square \square \square \square \square \square \square$

Data badania: $\square \square-\square \square-\square \square \square \square$ dzień — miesiąc — rok

\section{Obecny stan kliniczny:}

a) Badanie podmiotowe:

Główne dolegliwości:

$\square$ osłabienie, $\square$ łatwa męczliwość, $\square$ uczucie stałego zmęczenia,

$\square$ obniżenie nastroju, $\square$ zmniejszenie energii życiowej 
$\square$ pogorszenie kontaktów społecznych z nasiloną tendencją do izolacji

$\square$ zaburzenie reakcji emocjonalnych, $\square$ poczucie pogorszenia jakości życia

$\square$ brak poczucia zdrowia

Inne, opisz

\section{Badanie psychologiczne:}

Test psychologiczny oceny jakości życia (test QoL-AGHDA)

Inne:

b) Badanie przedmiotowe - data $\square \square-\square \square-\square \square \square \square$ dzień — miesiąc - rok
Wzrost: $\square \square \square, \square \mathrm{cm}$
Masa ciała: $\square \square \square \mathrm{kg}$
Obwód talii: $\square \square \square \mathrm{cm}$
Obwód bioder: $\square \square \square \mathrm{cm}$
BMI: $\square \square, \square \mathrm{kg} / \mathrm{m}^{2}$
WHR: $\square \square, \square$

Ciśnienie tętnicze krwi: $\square \square \square / \square \square \square \mathrm{mmHg}$

Częstość tonów serca: $\square \square \square / \mathrm{min}$

Odchylenia od stanu prawidłowego:

Głowa:

Szyja:

Klatka piersiowa:

Układ krążenia:

Układ oddechowy:

Brzuch:

Układ nerwowy:

Narządy płciowe:

Inne:

c) Badania dodatkowe:

\begin{tabular}{l|l|l|l|l}
\hline Badanie & Data & Wartość & Jednostki & Zakres normy \\
\hline IGF-I & & & & \\
\hline $\mathrm{TSH}$ & & & & \\
\hline $\mathrm{FT}_{4}$ & & & & \\
\hline Kortyzol & & & & \\
\hline Stężenie glukozy w surowicy & & & & \\
\hline Stężenie hemoglobiny glikowanej & & & & \\
\hline
\end{tabular}

\section{Lipidogram:}

\begin{tabular}{l|l|l|l|l}
\hline Badanie & Data & Wartość & Jednostki & Zakres normy \\
\hline Cholesterol całkowity & & & & \\
\hline Frakcja LDL-cholesterolu & & & & \\
\hline Frakcja HDL-cholesterolu & & & & \\
\hline Triglicerydy & & & & \\
\hline Lp(a) & & & & \\
\hline
\end{tabular}

Badania dotyczące funkcji nerek:

Badania dotyczące funkcji wątroby:

Badanie densytometryczne:

Data badania $\square \square-\square \square-\square \square \square \square$ 
Metoda:

\begin{tabular}{l|l|l|l|l|l}
\hline & Z-score & T-score & BMD [g/cm] & BMC [kg] & Uwagi \\
\hline Odcinek lędźwiowy kręgosłupa & & & & & \\
\hline Szyjka kości udowej & & & & & \\
\hline Badanie kośćca całego ciała & & & & & \\
\hline Inne & & & & & \\
\hline Inne & & & & & \\
\hline
\end{tabular}

Ocena składu masy ciała:

Badania MR lub badanie TK wykonane w ciągu ostatnich 6 miesięcy data $\square \square-\square \square-\square \square \square \square$

Inne:

3. Przebieg terapii:

Początek leczenia

Czas trwania leczenia

$\square \square-\square \square \square \square$ miesiąc - rok

Czy były przerwy w terapii od ostatniej obserwacji?

$\square \mathrm{T}$ - tak; $\mathrm{N}$ - nie

Preparat:

Stosowana dawka preparatu:

Schemat leczenia:

Czy wystąpiły powikłania podczas leczenia rhGH?

$\square \mathrm{T}$ - tak; $\mathrm{N}-$ nie

Jeśli tak, opisz

\section{Wymień leki aktualnie stosowane przez pacjenta:}

Nazwa leku ..................... dawka ............. początek stosowania $\square \square-\square \square \square \square$ m-r
Nazwa leku .................... dawka ............. początek stosowania $\square \square-\square \square \square \square$ m-r
Nazwa leku .................... dawka ............. początek stosowania $\square \square-\square \square \square \square$ m-r
Nazwa leku .................... dawka ............. początek stosowania $\square \square-\square \square \square \square$ m-r
Nazwa leku .................... dawka ............. początek stosowania $\square \square-\square \square \square \square$ m-r
Nazwa leku ................... dawka ............. początek stosowania $\square \square-\square \square \square \square$ m-r

\section{Data wystawienia karty: $\square \square-\square \square \square \square$}

Jednostka wypełniająca kartę:

Pełna nazwa:

Adres:

Telefon/fax:

Lekarz wystawiający kartę:

Imię i nazwisko:

Podpis i pieczątka:

Kierownik/Ordynator jednostki wystawiającej kartę:

Podpis i pieczątka: 


\section{Załącznik nr 5}

\section{OGÓLNOPOLSKI PROGRAM LECZENIA CIĘŻKIEGO NIEDOBORU HORMONU WZROSTU U LUDZI DOROSEYCH ORAZ U MKODZIEZYY PO ZAKOŃCZENIU TERAPII PROMUJACEJ WZRASTANIE (ICD-10 E23.0)}

\section{ŚWIADCZENIOBIORCY}

Do programu kwalifikuje Zespót Koordynacyjny ds. Stosowania Hormonu Wzrostu.

1. Kryteria kwalifikacji

1) Objawy niedoboru hormonu wzrostu.

2) Stężenie IGF-I poniżej zakresu wartości prawidłowych lub w dolnym przedziale zakresu referencyjnego.

3) Potwierdzenie ciężkiego niedoboru GH na podstawie:

a) u osób dorosłych nieleczonych w dzieciństwie z powodu GHD (AO-GHD) — obniżone wydzielanie GH (poniżej $3 \mathrm{ng} / \mathrm{ml}$ ) w dwóch różnych testach stymulacyjnych w przypadku izolowanej GHD lub w jednym teście stymulacyjnym w przypadku wielohormonalnej niedoczynności przysadki (testy muszą być wykonane po wcześniejszym właściwym wyrównaniu co najmniej niedoboru kortyzolu i L-tyroksyny);

b) u młodzieży i osób dorosłych leczonych wcześniej z powodu GHD (CO-GHD) —obniżone wydzielanie GH (poniżej 3 ng/ml) w dwóch różnych testach stymulacyjnych w przypadku izolowanej GHD lub w jednym teście stymulacyjnym w przypadku wielohormonalnej niedoczynności przysadki (testy muszą być wykonane po wcześniejszym właściwym wyrównaniu co najmniej niedoboru kortyzolu i L-tyroksyny);

c) w przypadku występowania wielohormonalnej niedoczynności przysadki w zakresie wszystkich osi (z wyjątkiem prolaktyny) i potwierdzeniem przyczyny organicznej lub genetycznej tego stanu możliwe jest odstąpienie od wykonania testów stymulacyjnych i przyznanie leczenia rhGH na podstawie obniżonego stężenia IGF-I.

4) Brak przeciwwskazań do terapii GH stwierdzonych na podstawie wyników badań ogólnych lub obrazowych (w szczególności MR okolicy podwzgórzowo-przysadkowej lub TK z kontrastem) w celu wykluczenia czynnego procesu nowotworowego.

Kryteria kwalifikacji muszą być spełnione łącznie.

\section{Określenie czasu leczenia w programie}

Leczenie trwa do czasu podjęcia przez lekarza prowadzącego lub Zespół Koordynacyjny ds. Stosowania Hormonu Wzrostu decyzji o wyłączeniu świadczeniobiorcy z programu, zgodnie z kryteriami wyłączenia.

\section{Kryteria wyłączenia}

1) Ujawnienie lub wznowa czynnego procesu nowotworowego.

2) Ciężkie stany zagrożenia życia.

3) Cukrzyca niedająca się wyrównać w warunkach leczenia rhGH.

4) Utrzymujące się podwyższone stężenie IGF-I, pomimo zmniejszenia dawki leku do minimalnej $(0,1 \mathrm{mg} / \mathrm{dziennie})$.

5) Wystąpienie nowych lub brak poprawy istniejących wcześniej zaburzeń metabolicznych i pogorszenia jakości życia mimo leczenia (ocena po 12 i 24 miesiącach).

6) Brak zgody świadczeniobiorcy na kontynuację leczenia lub brak wspótpracy świadczeniobiorcy.

\section{SCHEMAT DAWKOWANIA LEKÓW W PROGRAMIE}

\section{Dawkowanie}

Somatotropina podawana codziennie wieczorem w dawce: 0,1-0,8 $\mathrm{mg}$ dziennie.

\section{BADANIA DIAGNOSTYCZNE WYKONYWANE W RAMACH PROGRAMU}

\section{Badania przy kwalifikacji}

1) Ocena masy ciała i obwodu talii (wskaźnik BMI i WHR), zalecane: ocena składu ciała metodą bioimpedancji.

2) Pomiar ciśnienia tętniczego krwi.

3) Morfologia krwi z rozmazem.

4) Jonogram surowicy krwi (co najmniej pomiar stężenia $\mathrm{Na}, \mathrm{K} \mathrm{i} \mathrm{Ca).}$

5) Ocena stężenia IGF-I.

6) Ocena stężenia glukozy we krwi i odsetka glikowanej hemoglobiny $\left(\mathrm{HbA}_{1} \mathrm{c}\right)$ lub test obciążenia glukozą, z oceną glikemii i insulinemii.

7) Ocena stężenia triglicerydów; całkowitego cholesterolu, frakcji HDL-cholesterolu i LDL-cholesterolu.

8) Pomiar stężenia $\mathrm{TSH}_{\text {i FT}}$.

9) Pomiar stężenia kortyzolu w godzinach porannych.

10) Badanie jakości życia za pomocą odpowiedniego kwestionariusza (OoL).

11) Jeden lub dwa testy stymulujące sekrecję GH.

12) Obrazowanie okolicy podwzgórzowo-przysadkowej (MR lub TK z kontrastem).

13) USG jamy brzusznej.

14) EKG ewentualnie USG serca.

15) Badanie dna oka.

16) Inne badania i konsultacje w zależności od potrzeb. 


\section{Monitorowanie leczenia}

\subsection{Po 30 dniach od rozpoczęcia terapii:}

1) Pomiar stężenia IGF-1 w celu ustalenia dawki optymalnej.

\subsection{Co 180 dni:}

1) Ocena masy ciała i obwodu talii (wskaźnik BMI i WHR), zalecane: ocena składu ciała metodą bioimpedancji;

2) Pomiar ciśnienia tętniczego krwi;

3) Jonogram surowicy krwi (co najmniej pomiar stężenia $\mathrm{Na} \mathrm{i} \mathrm{Ca}$ );

4) Określenie odsetka glikowanej hemoglobiny HBA1c;

5) Ocena stężenia IGF-I;

6) Ocena stężenia $\mathrm{TSH}_{\text {i FT}}$;

7) Ocena stężenia triglicerydów; całkowitego cholesterolu, frakcji HDL-cholesterolu i LDL-cholesterolu;

8) Ocena QoL;

9) Inne badania i konsultacje w zależności od potrzeb.

\section{Monitorowanie programu}

1) Gromadzenie w dokumentacji medycznej świadczeniobiorcy danych dotyczących monitorowania leczenia i każdorazowe ich przedstawianie na żądanie kontrolerów Narodowego Funduszu Zdrowia.

2) Uzupełnienie danych zawartych w rejestrze SMPT dostępnym za pomocą aplikacji internetowej udostępnionej przez OW NFZ, z częstotliwością zgodną z opisem programu oraz na zakończenie leczenia.

3) Przekazywanie informacji sprawozdawczo-rozliczeniowych do NFZ: informacje przekazuje się do NFZ w formie papierowej lub w formie elektronicznej, zgodnie z wymaganiami opublikowanymi przez Narodowy Fundusz Zdrowia. 